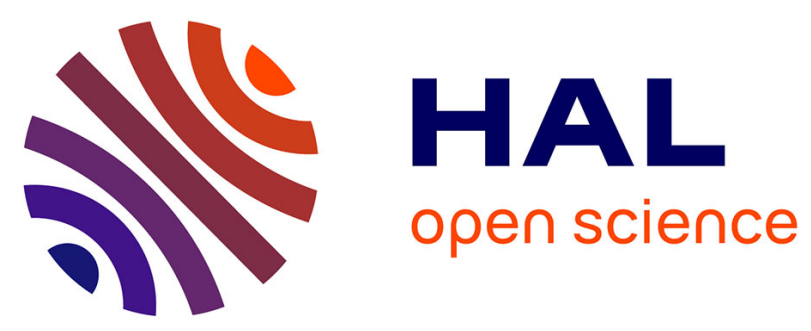

\title{
Allyl Complexes of Tungsten from the Rearrangement of Transient Cyclopropyl Precursors
}

\author{
Kyle Parker, Stephane Labat, Jean-Marc Sotiropoulos, Karinne Miqueu, \\ Véronique Pimienta, Laure Vendier, Michel Etienne
}

\section{- To cite this version:}

Kyle Parker, Stephane Labat, Jean-Marc Sotiropoulos, Karinne Miqueu, Véronique Pimienta, et al.. Allyl Complexes of Tungsten from the Rearrangement of Transient Cyclopropyl Precursors. European Journal of Inorganic Chemistry, 2019, 2019 (42), pp.4555-4563. 10.1002/ejic.201900816 . hal02309138

\section{HAL Id: hal-02309138 \\ https://hal.science/hal-02309138}

Submitted on 11 Nov 2020

HAL is a multi-disciplinary open access archive for the deposit and dissemination of scientific research documents, whether they are published or not. The documents may come from teaching and research institutions in France or abroad, or from public or private research centers.
L'archive ouverte pluridisciplinaire HAL, est destinée au dépôt et à la diffusion de documents scientifiques de niveau recherche, publiés ou non, émanant des établissements d'enseignement et de recherche français ou étrangers, des laboratoires publics ou privés. 


\title{
Allyl complexes of tungsten from the rearrangement of transient cyclopropyl precursors
}

\author{
Kyle D. J. Parker, ${ }^{[a]}$ Stéphane Labat, ${ }^{[b]}$ Jean-Marc Sotiropoulos, ${ }^{[b]}$ Karinne Miqueu ${ }^{*[b]}$
}

Véronique Pimienta, ${ }^{[c]}$ Laure Vendier ${ }^{[a]}$ and Michel Etienne ${ }^{*[a]}$

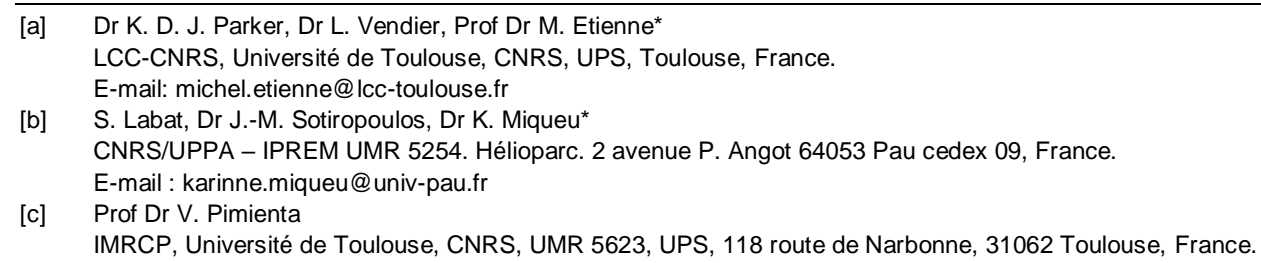

Abstract: This article explores the contrasting reactivity of cyclopropyl complexes of early transition metals. [Cp $\left.{ }^{*} \mathrm{~W}(\mathrm{NO})\left(\mathrm{CH}_{2} \mathrm{R}\right)\left(c-\mathrm{C}_{3} \mathrm{H}_{5}\right)\right]\left(\mathrm{R}=\mathrm{SiMe}_{3}, \mathrm{Ph}, t\right.$-Bu) generated in THF solution from $\left[\mathrm{Cp} * \mathrm{~W}(\mathrm{NO})\left(\mathrm{CH}_{2} \mathrm{R}\right) \mathrm{Cl}\right]$ and $\left.\left[\mathrm{Mg}\left(c-\mathrm{C}_{3} \mathrm{H}_{5}\right)_{2} \text { (dioxane }\right)_{\times}\right]$readily rearrange to $\eta^{3}$-allyl derivatives $\left[\mathrm{Cp}{ }^{*} \mathrm{~W}(\mathrm{NO})\left(\mathrm{CH}_{2} \mathrm{R}\right)\left(\eta^{3}-\mathrm{C}_{3} \mathrm{H}_{5}\right)\right]$ by an intramolecular ring opening reaction. Both direct and catalysed pathways are revealed by kinetic studies. Computational modeling indicates the ring opening reaction is preferred on thermodynamic grounds for tungsten whereas kinetic products arising from $\beta-\mathrm{H}$ abstraction reactions of cyclopropane are observed for related zirconium and niobium complexes reported previously. The energetic accessibility and the nature of the LUMO in the tungsten complexes promote distal CC bond cleavage in the cyclopropyl ring.

\section{Introduction}

Cyclopropyl groups bound to early transition metals have the ability to generate reactive $\eta^{2}$-cyclopropene/metallabicyclobutane intermediates via elimination of a $\beta$-hydrogen. ${ }^{[1]}$ The reaction is actually the intramolecular abstraction of a $\beta-\mathrm{H}$ by a hydrocarbyl group $\mathrm{R}$ cis to the cyclopropyl group in the initial complex (Scheme 1). The $\eta^{2}$ cyclopropene/metallabicyclobutane intermediate can be trapped or undergo functionalisation reactions such as oxidative coupling/insertion of unsaturated organic substrates. ${ }^{[1-3]}$ Zirconium and niobium $\eta^{2}$-cyclopropene/metallabicyclobutane intermediates thermally generated from well-defined cyclopropyl derivatives such as $\left[\mathrm{Cp}_{2} \mathrm{Zr}\left(c-\mathrm{C}_{3} \mathrm{H}_{5}\right)_{2}\right]$ and $\left[\mathrm{Tp}^{\mathrm{Me}} \mathrm{NbR}\left(c^{-}\right.\right.$ $\left.\left.\mathrm{C}_{3} \mathrm{H}_{5}\right)(\mathrm{MeCCMe})\right]\left[\mathrm{Tp}^{\mathrm{Me} 2}=\right.$ hydrotris(3,5-dimethylpyrazolyl)borate] can cleave a variety of $\mathrm{CH}$ bonds of unsaturated hydrocarbons $\mathrm{R}^{\prime} \mathrm{H}$. The products are $\left[\mathrm{Cp}_{2} \mathrm{ZrR}\left(c-\mathrm{C}_{3} \mathrm{H}_{5}\right)\right]^{[4]}$ and $\left[\mathrm{Tp}^{\mathrm{Me} 2} \mathrm{NbR}{ }^{\prime}\left(c-\mathrm{C}_{3} \mathrm{H}_{5}\right)(\mathrm{MeCCMe})\right]^{[5-8]}$ Structural and mechanistic studies established that the products are formed by the mechanistic reverse of the $\beta-\mathrm{H}$ abstraction reaction namely the 1,3-addition and cleavage of the $\mathrm{C}-\mathrm{H}$ bond of $\mathrm{R}^{\prime} \mathrm{H}$ across the $\left[\mathrm{M}\left(\eta^{2}-c-\mathrm{C}_{3} \mathrm{H}_{4}\right)\right]$ unit. This reactivity 
culminated with the activation of the notably strong and inert $\mathrm{C}-\mathrm{H}$ bond in methane with the niobium complexes. ${ }^{[9]}$ The intramolecular $\alpha-\mathrm{H}$ abstraction in dicyclopropyl titanocene generates a transient cyclopropylidene complex. ${ }^{[10]}$

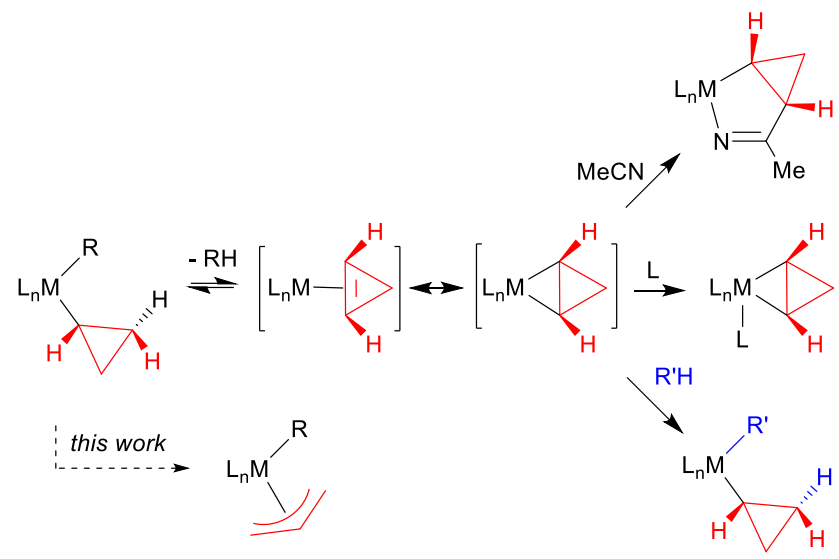

Scheme 1. Chemistry of early transition metal cyclopropyl alkyl complexes.

Inspired by the remarkable achievements of the Legzdins group in the area of $\mathrm{CH}$ bond activation with group 6 organometallics of the type [Cp'M(NO)RR'] (Cp' = a substituted cyclopentadienyl ligand; $M=M o, W ; R, R^{\prime}=$ hydrocarbyl ligands), ${ }^{[11,12]}$ many of them occurring through the $\beta-\mathrm{H}$ abstraction/1,3-CH bond activation sequence, ${ }^{[13-24]}$ we initiated a study aimed at extending our work to this organometallic platform. In a preliminary account, ${ }^{[25]}$ we reported that while the cyclopropyl complex $\left[\mathrm{Cp}{ }^{*} \mathrm{~W}(\mathrm{NO})\left(c-\mathrm{C}_{3} \mathrm{H}_{5}\right)\left(\mathrm{CH}_{2} \mathrm{SiMe}_{3}\right)\right]\left(\mathrm{Cp}^{*}=\eta^{5}-\mathrm{C}_{5} \mathrm{Me}_{5}\right)$ could be cleanly generated at low temperature, it was thermally unstable with respect to cyclopropyl ring opening such that the $\beta-\mathrm{H}$ abstraction could not be studied, the isomeric $\eta^{3}$-allyl complex $\left[\mathrm{Cp} * \mathrm{~W}(\mathrm{NO})\left(\eta^{3}-\mathrm{C}_{3} \mathrm{H}_{5}\right)\left(\mathrm{CH}_{2} \mathrm{SiMe}_{3}\right)\right]$ being formed instead.

The opening of the cyclopropyl ring in cyclopropyl metal complexes is known. The Jones group summarised the main outcomes some 30 years ago.[26] Among the several possible rearrangements, it was found that, at least for late transition metals in various oxidation states, an unsaturated coordination sphere with a 16-e count or less was a necessary, though not sufficient, prerequisite for the generation of $\eta^{3}$-allyl species. Beyond metal insertion into the distal CC bond leading directly to the allyl species or initial generation of a metallacyclobut-1-ene by insertion into the proximal $\mathrm{CC}$ bond, different intimate mechanisms can be at play depending on the metal and the substitution pattern of the cyclopropyl ligand.[26-28] High valent early transition metal cyclopropyl complexes are conspicuously absent from this list of isomerising complexes. The ring-opening by distal CC bond cleavage in model cyclopropyl samarocene is found computationally to occur with a prohibitively high energy barrier. ${ }^{[29]}$ Products arising from coupling of the alkyne ligand with a 
ring-opened cyclopropyl ligand have been observed in selected cases in $\left[\mathrm{Tp}^{\mathrm{Me}} \mathrm{NbR}\left(c^{-}\right.\right.$ $\left.\left.\mathrm{C}_{3} \mathrm{H}_{5}\right)(\mathrm{MeCCMe})\right]$ but no mechanistic details are available. ${ }^{[5]}$

Although frustrating with respect to $\mathrm{CH}$ bond activation of interest, we report herein a structural, mechanistic and computational study of this rearrangement showing it is the rule for cyclopropyl alkyl complexes $\left[\mathrm{Cp} * \mathrm{~W}(\mathrm{NO})\left(c-\mathrm{C}_{3} \mathrm{H}_{5}\right)\left(\mathrm{CH}_{2} \mathrm{R}\right)\right]\left(\mathrm{R}=\mathrm{SiMe}_{3}, \mathrm{Ph}, t-\mathrm{Bu}\right)$. The results are discussed in the light of well-established precedents of ring-opening of unsaturated complexes and comparison with early transition metal complexes undergoing $\beta-\mathrm{H}$ abstraction reactions.

\section{Results and Discussion}

\section{Synthetic and structural aspects}

As communicated initially for the methyltrimethylsilyl derivative, ${ }^{[25]}$ the addition of 0.5 equivalent of $\left.\left[\mathrm{Mg}\left(c-\mathrm{C}_{3} \mathrm{H}_{5}\right)_{2} \text { (dioxane) }\right)_{x}\right]$ to a solution of $\left[\mathrm{Cp}{ }^{*} \mathrm{~W}(\mathrm{NO})\left(\mathrm{CH}_{2} \mathrm{R}\right) \mathrm{Cl}\right](\mathbf{1}-\mathbf{R}=\mathbf{1 - S i M e}, \mathbf{1}$ $\mathbf{P h}, \mathbf{1 - t}-\mathbf{B u})^{[30,31]}$ in THF at $-35^{\circ} \mathrm{C}$ led to rapid colour changes indicative of the quantitative formation of the cyclopropyl complexes $\left[\mathrm{Cp}{ }^{*} \mathrm{~W}(\mathrm{NO})\left(c-\mathrm{C}_{3} \mathrm{H}_{5}\right)\left(\mathrm{CH}_{2} \mathrm{R}\right)\right]\left(\mathbf{2}-\mathbf{R}=\mathbf{2}-\mathbf{S i M e}_{3}, \mathbf{2}-\mathbf{P h}, \mathbf{2}-\right.$ $\boldsymbol{t}$-Bu). As indicated in Scheme 2, we were not able to isolate these complexes as work-up induced (see below) the rearrangement of 2-R (especially $\mathbf{2}-\mathbf{P h}$ ) to the corresponding $\eta^{3}$-allyl complexes [Cp*W(NO) $\left.\left(\eta^{3}-\mathrm{C}_{3} \mathrm{H}_{5}\right)\left(\mathrm{CH}_{2} \mathrm{R}\right)\right]$ (3-R = 3-SiMe 3 , 3-Ph, 3-t-Bu). Complexes 3-R also formed slowly upon standing in THF at rt (3-SiMe, $30 \mathrm{~h} ; 3-\mathrm{Ph} 20 \mathrm{~h} ; \mathbf{3 - t - B u} 5 \mathrm{~d})$. Although 3-tBu did not form cleanly, 3-SiMe 3 and 3-Ph were isolated in 62-65\% yield. 3-SiMe $\mathbf{S}_{3}$ could be obtained independently by the reaction of $1-\mathrm{SiMe}_{3}$ with 0.5 equivalent of the allyl magnesium compound $\left[\mathrm{Mg}\left(n-\mathrm{C}_{3} \mathrm{H}_{5}\right)_{2} \text { (dioxane) }\right)_{\mathrm{x}}$. Each complex $\mathbf{3 - R}$ was fully characterised by elemental analysis, IR and NMR spectroscopy; the data for 3-t-Bu matched those reported previously. The allyl chloro complex $\left[\mathrm{Cp} * \mathrm{~W}(\mathrm{NO})\left(\eta^{3}-\mathrm{C}_{3} \mathrm{H}_{5}\right) \mathrm{Cl}\right](4)$ was formed similarly from $\left[\mathrm{Cp} * \mathrm{~W}(\mathrm{NO}) \mathrm{Cl}_{2}\right]$ and 0.5 equivalent of $\left.\left[\mathrm{Mg}\left(c-\mathrm{C}_{3} \mathrm{H}_{5}\right)_{2} \text { (dioxane }\right)_{x}\right]$ but no efforts were made to observe the putative cyclopropyl intermediate $\left[\mathrm{Cp} * \mathrm{~W}(\mathrm{NO})\left(c-\mathrm{C}_{3} \mathrm{H}_{5}\right) \mathrm{Cl}\right]^{[25]}$

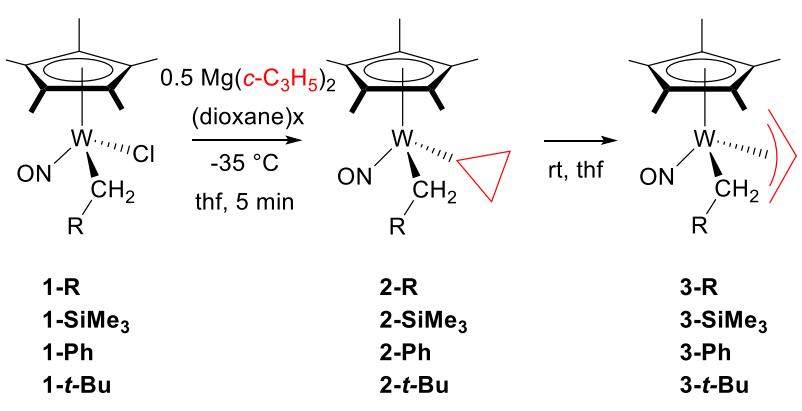

Scheme 2. Formation of cyclopropyl derivatives and their rearrangement to $\eta^{3}$-allyl complexes. 
The ${ }^{13} \mathrm{C}$ spectra of complexes $2-\mathbf{R}$ in THF- $d_{8}$ exhibit signals characteristic of a cyclopropyl ring. A W-bound $\mathrm{C} \alpha$ resonance is present as a doublet due to the coupling to one $\mathrm{H}\left({ }^{1} J_{\mathrm{CH}} \approx 145 \mathrm{~Hz}\right)$ as well as satellites due to coupling with ${ }^{183} \mathrm{~W}(\mathrm{I}=1 / 2,14.3 \%$ abundance, ${ }^{1} J_{\mathrm{CW}} \approx 125 \mathrm{~Hz}$ ). The signal for 2-Ph is significantly shielded at $\delta 26.6$ by comparison with those for 2-SiMe $3(\delta 65.0)$ and 2-t-Bu $(\delta 55.7)$. Two $\mathrm{C} \beta$ resonances are also observed as doublet of doublets in the $\delta 15-9$ region with ${ }^{1} J_{\mathrm{CH}} \approx 160 \mathrm{~Hz}$. In the ${ }^{1} \mathrm{H}$ NMR spectra, the accompanying resonances for the $\mathrm{H} \alpha$ and inequivalent diastereotopic $\mathrm{H} \beta$, all appearing as complex multiplets, are identified by ${ }^{1} \mathrm{H}-{ }^{13} \mathrm{C}$ HMQC experiments. These NMR data match those seen for similar cyclopropyl $\mathrm{Nb}$ or $\mathrm{Zr}$ complexes. ${ }^{[4,5,7]}$ The other alkyl group of 2- $\mathbf{R}$ is similarly identified by NMR spectroscopy. Key features include (i) in the ${ }^{1} \mathrm{H}$ NMR spectra, two doublets assigned to the diastereotopic $\mathrm{WCH}_{2} \mathrm{R}$ (viz for 2-t-Bu $\delta 3.18$ and $-1.52,{ }^{2} \mathrm{~J}_{\mathrm{HH}}=12 \mathrm{~Hz}$ ), (ii) in the ${ }^{13} \mathrm{C} \mathrm{NMR}$ spectra, a resonance for $\mathrm{WCH}_{2} \mathrm{R}$ appearing as a triplet or doublet of doublets [2-SiMe,$\delta 51.4$ $\left(\mathrm{dd},{ }^{1} \mathrm{~J}_{\mathrm{CH}}=117,99 \mathrm{~Hz}\right.$ ); 2-t-Bu, $\delta 99.8$ (pt, ${ }^{1} \mathrm{~J}_{\mathrm{CH}}=128 \mathrm{~Hz}$ )]; each of these resonances also

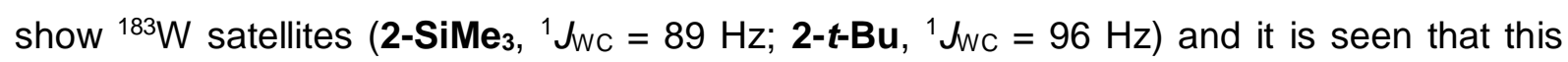
coupling is significantly smaller than that to the cyclopropyl $C \alpha$ reflecting, in accord with a similar ${ }^{1} J_{\mathrm{CH}}$ variation, the greater degree of $\mathrm{sp}^{2}$ hybridisation in the strained ring. The benzyl ligand in 2-Ph shows clear signs of $\eta^{2}$-coordination as observed ${ }^{[31]}$ in $\left[\mathrm{Cp}{ }^{*} \mathrm{WX}(\mathrm{NO})\left(\mathrm{CH}_{2} \mathrm{Ph}\right)\right](\mathrm{X}$ $=\mathrm{Cl}$, alkyl): in the ${ }^{13} \mathrm{C}$ NMR spectrum, the $\mathrm{WCH}_{2} \mathrm{R}$ shows a high ${ }^{1} \mathrm{~J}_{\mathrm{CH}}$ indicating $\mathrm{sp}^{2}$ character at carbon and a low ${ }^{1} J_{W C}\left[\delta 46.80\left(p t,{ }^{1} J_{\mathrm{CH}}=142 \mathrm{~Hz},{ }^{1} J_{\mathrm{WC}}=51 \mathrm{~Hz}\right)\right]$ and the $\mathrm{CH}_{2} \mathrm{Ph}$ ipso carbon is shielded at $\delta$ 118.5. In the ${ }^{1} \mathrm{H}$ NMR spectrum, the diastereotopic methylene protons $\mathrm{CH}_{2} \mathrm{Ph}$ appear as doublets at $\delta 3.17$ and 1.83 with a low $J_{H H}\left({ }^{2} J_{\mathrm{HaHb}}=6 \mathrm{~Hz}\right)$. Despite their ready rearrangement above $-35^{\circ} \mathrm{C}$, IR spectra of $2-R$ could be obtained and $v_{\text {NO }}$ stretches amount to $1572 \mathrm{~cm}^{-1}$ for 2-SiMe 3 and 2-Ph, and $1564 \mathrm{~cm}^{-1}$ for 2-t-Bu.

As depicted in Scheme 2, cyclopropyl complexes 2-R isomerise to the $\eta^{3}$-allyl derivatives 3-R. The isolated yield of 3-t-Bu (32\%) was significantly lower than that for $\mathbf{3}-\mathbf{S i M e}_{3}$ and 3-Ph (62\%). The tungsten centre is slightly less electron rich in 3-R than in $\mathbf{2}-\mathbf{R}$ as indicated by the higher $v_{N O}\left(c a 1584 \mathrm{~cm}^{-1}\right.$ ) possibly reflecting the weaker $\sigma$-donating, superior $\pi$ accepting ability of the $\eta^{3}$-allyl ligand as compared to the cyclopropyl group. Prominent ${ }^{1} \mathrm{H}$ and ${ }^{13} \mathrm{C}$ NMR features are akin to those reported for $3-\mathrm{SiMe}_{3}$. For the $\eta^{3}$-allyl group, one methylene carbon $\mathrm{C} \alpha$ is shielded around $\delta 40\left(\mathrm{t},{ }^{1} \mathrm{~J}_{\mathrm{CH}} \approx 150 \mathrm{~Hz}\right)$, whereas the other methylene carbon $\mathrm{C} \gamma$ is deshielded around $\delta 80\left(\mathrm{t},{ }^{1} \mathrm{~J}_{\mathrm{CH}} \approx 155 \mathrm{~Hz}\right)$; the methine $\mathrm{C} \beta$ gives a doublet in the $\delta 108-112$ range $\left({ }^{1} J_{\mathrm{CH}} \approx 163 \mathrm{~Hz}\right)$. Coupling to ${ }^{183} \mathrm{~W}$ is seen at $\mathrm{C} \alpha$ only for $3-\mathbf{S i M e}_{3}\left({ }^{1} \mathrm{~J}_{\mathrm{CW}}=56 \mathrm{~Hz}\right)$ and 3Ph $\left({ }^{1} J_{\mathrm{CW}}=24 \mathrm{~Hz}\right)$. HMQC experiments correlate these resonances to five more of less resolved multiplets in the ${ }^{1} \mathrm{H}$ NMR spectra. For $3-\mathrm{Ph}$, two inequivalent $\mathrm{H} \alpha$ were observed at $\delta$ 2.32 and $0.91, \mathrm{H} \gamma$ at $\delta 3.46$ and 2.10 and the methine $\mathrm{H} \beta$ resonates at $\delta 4.39$ in THF- $d_{8}$. The 
alkyl group $\mathrm{CH}_{2} \mathrm{R}$ is also identified by characteristic ${ }^{1} \mathrm{H}$ and ${ }^{13} \mathrm{C}$ NMR data (see experimental section). As established by ${ }^{13} \mathrm{C}$ NMR data, the benzyl group is $\eta^{1}$-bound with an ipso-carbon observed at $\delta 153.9$ and a shielded $\mathrm{W} C \alpha$ at $\delta 20.7$ with a low ${ }^{1} J_{\mathrm{CH}}\left(\mathrm{t},{ }^{1} J_{\mathrm{CH}}=127 \mathrm{~Hz}\right)$ and ${ }^{1} J_{\mathrm{CW}}$ $=74 \mathrm{~Hz}$.

The crystal molecular structure of 3-Ph (Figure 1 and its caption) is fully similar to that of 3-SiMe 3 and akin to those of closely related $\eta^{3}$-allyl complexes in the family. ${ }^{[11,16,17]}$ As often seen, the endo conformation of the $\eta^{3}$-allyl ligand is accompanied by a slippage of the allyl group towards a $\sigma / \pi$ mode owing to electronic asymmetry at the metal centre. ${ }^{[11,16,17,32]}$ The $W(1)-C(1)$ bond, similar to the trans $W(1)-C(4)$ bond with the $\eta^{1}$-benzyl group, is significantly shorter than the $\mathrm{W}(1)-\mathrm{C}(2)$ and $\mathrm{W}(1)-\mathrm{C}(3)$ bonds; the somewhat short $\mathrm{C}(2)-\mathrm{C}(3)$ bond, trans to the NO ligand, exhibits more double bond character than $\mathrm{C}(1)-\mathrm{C}(2)$.

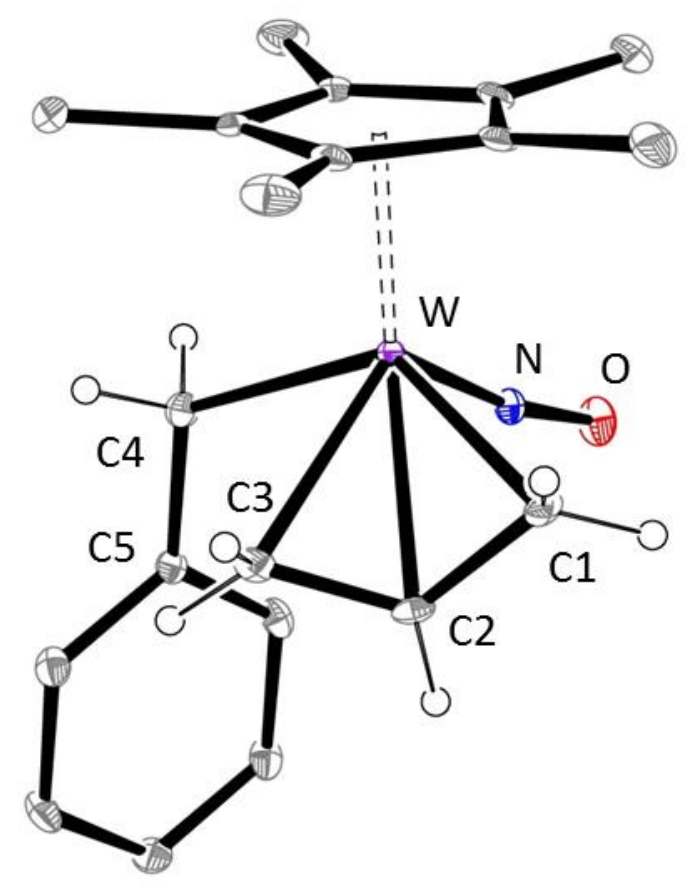

Figure 1. Solid state molecular structure of 3-Ph with selected hydrogen atoms shown as simple spheres. Relevant bond lengths $(\AA)$ and angles $\left({ }^{\circ}\right)$ : W(1) $-C(1) 2.240(3), W(1)-C(2)$ 2.315(3), W(1)-C(3) 2.382(3), W(1)-C(4) 2.252(3), C(1)-C(2) 1.430(5), C(2)-C(3) 1.382(5), $\mathrm{C}(4)-\mathrm{C}(5)$ 1.491(5), $\mathrm{W}(1)-\mathrm{N}(1)$ 1.777(3), $\mathrm{N}(1)-\mathrm{O}(1)$ 1.223(4); $\mathrm{C}(1)-\mathrm{C}(2)-\mathrm{C}(3)$ 117.8(3), $\mathrm{W}(1)-\mathrm{C}(4)-\mathrm{C}(5) 117.9(2), \mathrm{W}(1)-\mathrm{N}(1)-\mathrm{O}(1) 170.9(3)$.

\section{Rearrangement of 2-R to 3-R}

Qualitative observations. All attempts to isolate cyclopropyl complexes 2-R have failed. Removing the THF solvent at $-35^{\circ} \mathrm{C}$ induces a colour change towards that of $\mathbf{3}-\mathbf{R}$ which is confirmed by NMR monitoring. While pumping the solution to dryness at $-78^{\circ} \mathrm{C}$ initially 
maintains the colour of $\mathbf{2 - R}$, a rise in temperature to $\mathrm{ca}-50^{\circ} \mathrm{C}$ or the addition of any other solvent ( $v i z$ toluene) for extraction purposes at low temperature immediately results in a colour change to that of 3-R. The rearrangement is slowed down, although not supressed, by the addition of $\mathrm{PMe}_{3}$ to a solution of 2-R. Not only is the colour of $\mathbf{2 - R}$ maintained but a ${ }^{31} \mathrm{P}\left\{{ }^{1} \mathrm{H}\right\}$ NMR spectrum shows the presence of a broad signal at $\delta-56$ (versus free $\mathrm{PMe}_{3} \delta-62$ ) suggesting the formation of a labile, formally $18 \mathrm{e}$, complex such as [2-R(PMe $)$ ]. However, removing the volatiles at this stage produced a residue whose colour was indicative of the formation of 3-R, a result which was confirmed by NMR spectroscopy. These observations collectively suggest a non-trivial kinetic behaviour for the cyclopropyl ring opening in 2-R.

Kinetic studies. Kinetic studies were undertaken to better understand the rearrangements of 2-SiMe $\mathbf{S}_{3}$ and 2-Ph. A solution of 2-R in THF- $d_{8}$ was freshly prepared and its disappearance was followed by ${ }^{1} \mathrm{H}$ NMR spectroscopy over more than three half-lives. For $2-\mathrm{SiMe}_{3}$ both the $\mathrm{Cp}^{*}$ and $\mathrm{SiMe}_{3}$ resonances are monitored allowing for a more accurate determination. No intermediates could be identified in the spectra. Figure 2 shows first-order kinetic plots for the rearrangement of $2-\mathrm{SiMe}_{3}\left(\left[2-\mathrm{SiMe}_{3}\right]_{0}=0.215 \mathrm{~mol} / \mathrm{L}, k_{298}=3.19 \times 10^{-5} \mathrm{~s}^{-1}\right)$. At a similar initial concentration, 2-Ph rearranges faster likely reflecting a less congested coordination sphere $\left([2-\mathrm{Ph}]_{0}=0.222 \mathrm{~mol} / \mathrm{L}, k_{298}=1.46 \times 10^{-4} \mathrm{~s}^{-1}\right)$. An Eyring plot for $2-\mathbf{S i M e}_{3}$ in the $288-318 \mathrm{~K}$ range yields activation parameters that suggest an intramolecular process with an ordered transition state $\left(\Delta \mathrm{H}^{\ddagger}=84 \pm 8 \mathrm{~kJ} / \mathrm{mol} ; \Delta \mathrm{S}^{\ddagger}=-55 \pm 10 \mathrm{~J} / \mathrm{K}\right.$.mol) (see Supporting Information).

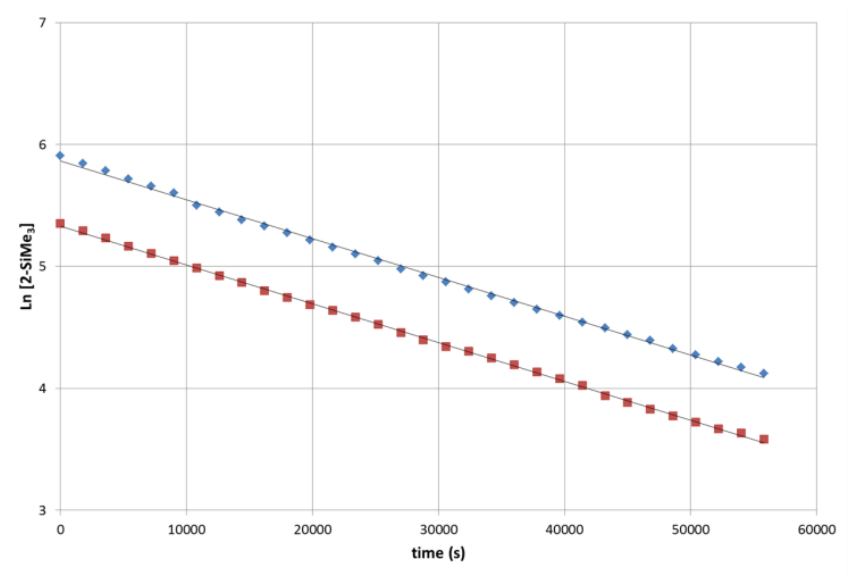

Figure 2. First-order kinetic plot with linear fit for the disappearance of 2-SiMe 3 ([2-SiMe $]_{0}=$ $0.215 \mathrm{~mol} / \mathrm{L}, \mathrm{T}=298 \mathrm{~K}$ ) as followed by ${ }^{1} \mathrm{H} \mathrm{NMR}$ ( $\bullet, \mathrm{Cp}^{*}$ resonance; $\cdot \mathrm{SiMe}_{3}$ resonance).

However, the observed rate constant depends on the initial concentration as can be seen from Figure 3 which also provides a reasonable linear fit $\left(R^{2}=0.924\right)$ with $k_{298}=(1.05 \times$ $\left.10^{-4}\right)\left[2-\mathrm{SiMe}_{3}\right]_{0}+\left(6.84 \times 10^{-6}\right)$. For $\mathbf{2}-\mathrm{SiMe}_{3}$, two experiments at the same initial concentration $\left(\left[2-\mathrm{SiMe}_{3}\right]_{0}=0.121 \mathrm{~mol} / \mathrm{L}\right)$ conducted either in the presence of solid $\mathrm{MgCl}_{2}$ or after filtration 
give the same rate constants ruling out the involvement of aggregates or magnesium containing species in the rearrangement. The presence of TEMPO, 2,6-tert-butylphenol (ca 5 equiv) or traces of $\mathrm{O}_{2}$ does not significantly change the rate of the rearrangements suggesting a radical pathway is not operative.

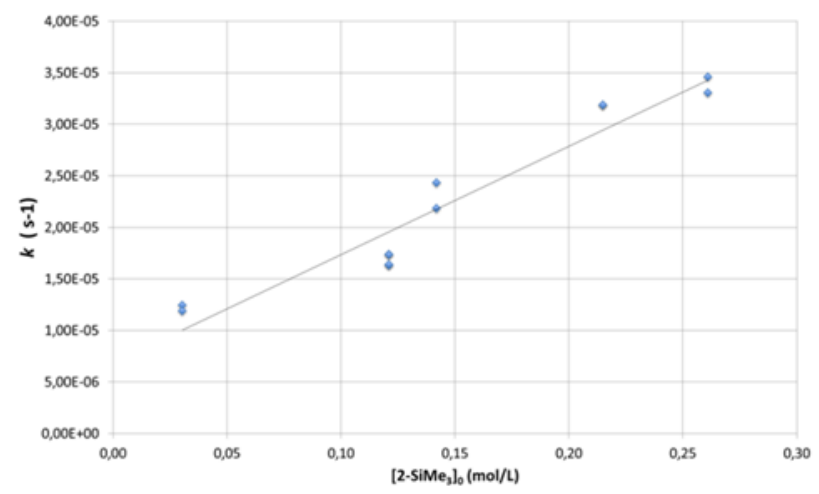

Figure 3. Plot of the observed rate constant $k_{298}$ for the isomerisation of $2-\mathrm{SiMe}_{3}$ to $3-\mathrm{SiMe}_{3}$ as a function of the initial concentration $\left[2-\mathrm{SiMe}_{3}\right]_{0}$.

Since the dependence of $k$ with the initial concentration was puzzling, a detailed simulation of the reaction profile based on plausible reaction mechanisms has been undertaken. Several models have been tested by fitting simultaneously three independent experiments with different initial concentrations of 2- SiMe reproduces the experimental data consists of two parallel elementary steps (1) and (2) with rate constants $k_{1}$ and $k_{2}$, respectively, one of them being catalysed: 
(1) $2-\mathrm{SiMe}_{3} \rightarrow$ 3-SiMe 3

(2) $2-\mathrm{SiMe}_{3}+\mathrm{C} \rightarrow 3-\mathrm{SiMe}_{3}+\mathrm{C}$

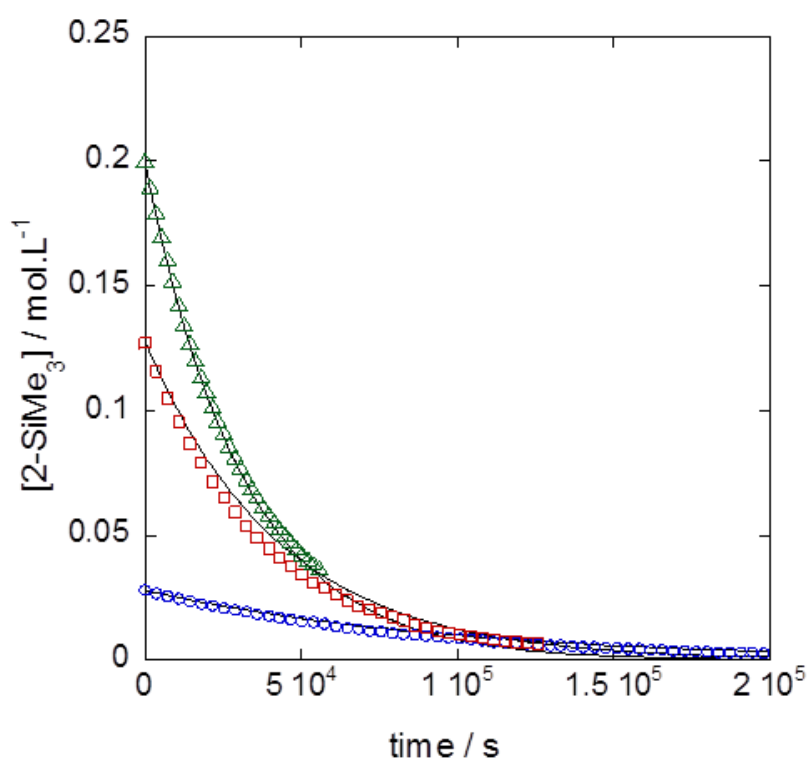

Figure 4. Concentration of $2-\mathrm{SiMe}_{3}$ as a function of time for three different initial concentrations: $\circ 0.028 ; \square 0.128 ; \Delta 0.20 \mathrm{~mol} / \mathrm{L}$. Discrete symbols represent the experimental points and continuous lines are provided by the simulation.

The experimental and simulated curves are represented in Figure 4. Although we were not able to identify the nature of the catalytic species $\mathbf{C}$ (see above), its concentration is chosen to be proportional to the initial concentration of $2-\mathbf{S i M e}_{3}$ as suggested by the experimental observations. The rate constant $k_{1}$ is fixed to the value obtained by the experimental linear fit in Figure $3\left(k_{1}=6.84 \times 10^{-6} \mathrm{~s}^{-1}\right)$, the concentration of the catalyst being set arbitrarily to [2$\left.\mathrm{SiMe}_{3}\right]_{0} / 1000$. The only fitted parameter is then the rate constant of the catalysed path $k_{2}$, quantitatively providing the product $k_{2}[\mathbf{C}]$. Finally, by fitting only one parameter the set of experiments is correctly reproduced within the experimental error observed in Figure 3 . The error between experimental and calculated curves is higher (the residual quadratic error is multiplied by a factor 15) than the one obtained using a first order rate law but in this case a common set of parameters reproduces the three experiments. By optimising the initial concentration of $\mathbf{C}$, a perfect fit can be obtained; however, we feel this is of minimal probative value to the present system under study. We note that this model can also be interpreted by including a fast pre-equilibrium involving $2-\mathbf{S i M e}_{3}$ and the unknown catalyst $\mathbf{C}$ leading to the

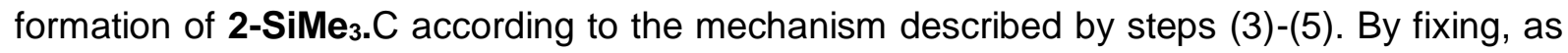
previously, the concentration of $\mathbf{C}$ to $\left[2-\mathrm{SiMe}_{3}\right]_{0} / 1000$ and the rate constant $k_{4}$ of the free 
reactant to the value obtained in Figure 3 , the kinetics is equivalent to the preceding one fitting equally well with the observed experimental data.

$\begin{array}{ccc}\rightleftarrows & \text { (3) } 2-\mathrm{SiMe}_{3}+\mathrm{C} & 2-\mathrm{SiMe}_{3} \mathrm{C} \\ \rightarrow & \text { (4) } 2-\mathrm{SiMe}_{3} & 3-\mathrm{SiMe}_{3} \\ \rightarrow & \text { (5) } 2-\mathrm{SiMe}_{3} . \mathrm{C} & 3-\mathrm{SiMe}_{3}+\mathrm{C}\end{array}$

\section{Computational studies}

Computational studies - DFT at the PBE0/SDD+f(W),6-31G**(other atoms) level of theory - were conducted with the aim of probing the ease of the cyclopropyl ring opening leading from 2-SiMe 3 to $3-\mathrm{SiMe}_{3}$ as compared to the expected $\beta-\mathrm{H}$ abstraction reaction leading to the putative $\eta^{2}$-cyclopropene/tungstabicyclobutane intermediate $\left[\mathrm{Cp} * \mathrm{~W}(\mathrm{NO})\left(\eta^{2}-c-\mathrm{C}_{3} \mathrm{H}_{4}\right)\right] \mathbf{A}$ akin to the zirconium $\left[\mathrm{Cp}_{2} \mathrm{Zr}\left(\eta^{2}-c-\mathrm{C}_{3} \mathrm{H}_{4}\right)\right]$ and niobium $\left[\mathrm{Tp}^{\mathrm{Me} 2} \mathrm{Nb}\left(\eta^{2}-c-\mathrm{C}_{3} \mathrm{H}_{4}\right)(\mathrm{MeCCMe})\right]$ intermediates previously characterised. Energy profiles for the two plausible mechanisms involving 2-SiMe $\mathbf{S}_{3}$ are presented in Figure 5 (see also Figure S24, Supporting Information). To get more refined free energies, single point calculations including dispersion and solvent effects have been carried out at the SMD(THF)-PBE0-D3(BJ)/SDD+f(W), 6-311++G** (other atoms) level of theory (labelled corr in Figure 5). They do not alter the more significant conclusions of the study.

A detailed analysis of 2-SiMe 3 testifies to the presence of a $\mathrm{C} \alpha \mathrm{C} \beta$ ( $\equiv \mathrm{C} 1-\mathrm{C} 2$ ) agostic interaction, ${ }^{[33,34]}$ as revealed by the CC bond elongation (C1-C2 $1.554 \AA$ ) and the NBO analysis. A donor acceptor interaction $\sigma_{\mathrm{C}_{\alpha} \mathrm{C} \beta} \rightarrow \mathrm{LP}^{*}(\mathrm{~W})$ has been found at the $2^{\text {nd }}$ order perturbation theory level with a stabilising interaction $\Delta \mathrm{E}(2)$ at around $72 \mathrm{~kJ} / \mathrm{mol}$ and the Natural Localized Molecular Orbital (NLMO) associated to this $\sigma_{\mathrm{C} \alpha \mathrm{C} \beta}$ orbital involves a degree of metal centre participation around $4.7 \%$ (Table S1, Supporting Information), similar to what is seen in $\left[\mathrm{Cp}_{2} \mathrm{Zr}\left(c-\mathrm{C}_{3} \mathrm{H}_{5}\right)_{2}\right]$ (vide infra). ${ }^{[4]}$ In agreement with the experimental observations, the formation of 3-SiMe 3 is thermodynamically favoured compared to $\mathbf{A}+\mathrm{SiMe}_{4}$, with an exergonic process for the cyclopropyl ring opening $(\Delta \mathrm{G}=-65 \mathrm{~kJ} / \mathrm{mol})$ and a strongly endergonic process for $\beta-\mathrm{H}$ abstraction $(\Delta \mathrm{G}=+58 \mathrm{~kJ} / \mathrm{mol})$. Calculations indicate that the ring opening occurs at the distal $C \beta-C \beta$ ' bond in a single step mechanism via a disrotatory process ${ }^{[26]}$ and an activation barrier of $\Delta \mathrm{G}^{\ddagger}=123 \mathrm{~kJ} / \mathrm{mol}$. The associated transition state (TS1) is a late transition state with $\mathrm{W}-\mathrm{C} \alpha$ $2.180 \AA$ and $\mathrm{W}-\mathrm{C} \beta 2.116 \AA$. The latter is strongly shortened (47.3\%) compared to 2-SiMe 3 . In TS1, the $\mathrm{C} \alpha-\mathrm{C} \beta$ and $\mathrm{C} \beta-\mathrm{C} \beta$ ' bonds are lengthened by $5.3 \%(1.637 \AA$ versus $1.554 \AA$ ) and $41.2 \%(2.218 \AA$ versus $1.500 \AA)$, respectively, as compared to 2-SiMe 3 . Thereby, the $\mathrm{C} \alpha \mathrm{C} \beta$ bond is strongly activated at the TS, as is apparent in the $\Delta \mathrm{E}(2)$ stabilisation energy associated 
to the interaction $\mathrm{C} \alpha \mathrm{C} \beta \rightarrow \mathrm{M}(379 \mathrm{~kJ} / \mathrm{mol}$, Table S2, Supporting Information) and in the NLMO, which presents a significant participation of the metal centre $(12.1 \% \mathrm{~W})$. Along these lines, the cleavage of the $C \beta-C \beta$ ' bond has progressed to a very advanced state.

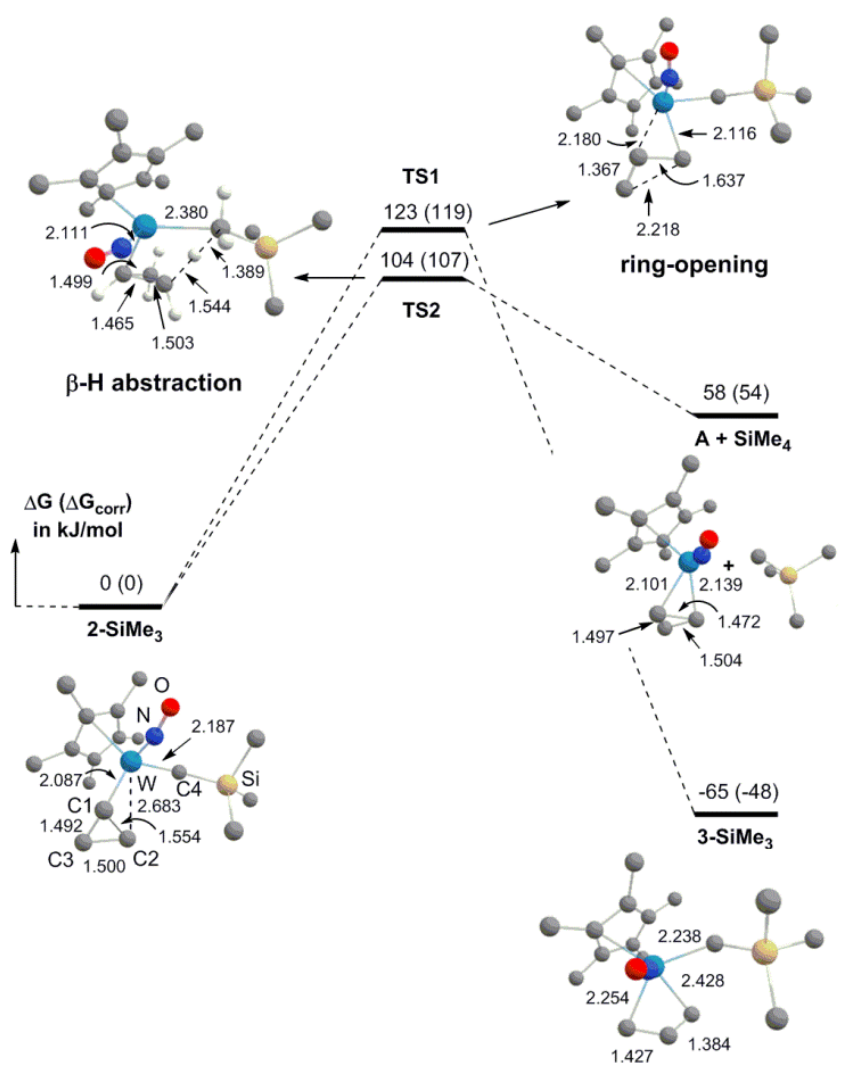

Figure 5. Computed free energy profiles and relevant bond distances $(\AA)$ for the ring opening and $\beta-\mathrm{H}$ abstraction from 2-SiMe 3 computed at PBE0/SDD+f(W),6-31G** level of theory. $\Delta \mathrm{G}$ values in $\mathrm{kJ} / \mathrm{mole}$ and corrected $\Delta \mathrm{G}$ values into bracket at SMD(THF)-PBE0-D3/SDD+f(W),6$311++G^{* *} / /$ PBE0/SDD+f(W),6-31G** level of theory.

The other competitive pathway, $\beta-\mathrm{H}$ abstraction, proceeds with a close but slightly lower activation barrier (TS2, $\Delta \mathrm{G}^{\ddagger}=104 \mathrm{~kJ} / \mathrm{mol}$ ). Nevertheless, this process is thermodynamically unfavourable. In light of these computational results, the experimentally observed formation of $\eta^{3}$-allyl derivative 3-SiMe 3 , can be explained by thermodynamic control of the reaction, albeit with an activation for ring opening barrier $\left(\Delta \mathrm{G}^{\ddagger}=123 \mathrm{~kJ} / \mathrm{mol}\right)$ accessible under the experimental conditions $\left(t_{1 / 2} \approx 6-14 \mathrm{~h}\right)$.

To understand the different behaviour of the zirconium and niobium complexes $\left[\mathrm{Cp}_{2} \mathrm{Zr}\left(c-\mathrm{C}_{3} \mathrm{H}_{5}\right)_{2}\right]$ and $\left[\mathrm{Tp}^{\mathrm{Me} 2} \mathrm{Nb}\left(c-\mathrm{C}_{3} \mathrm{H}_{5}\right)\left(\mathrm{CH}_{3}\right)(\mathrm{MeCCMe})\right]$ complexes, for which $\beta-\mathrm{H}$ abstraction is observed, calculations have also been performed on these two systems (Figure S25-S26 for energy profiles, Supporting Information) at the PBE0/SDD+f(M),6-31G** (other atoms) level of theory. The results are similar to those obtained previously with slightly different basis sets. ${ }^{[4,9]}$ Comparison between the three complexes highlights analogies but also differences for the $\beta$ - 
$\mathrm{H}$ abstraction and ring opening mechanisms, which are mainly associated with the electronic structure of the reactant. Indeed, the activation barrier for the $\beta-\mathrm{H}$ abstraction is similar in the three cases, at around 105 to $115 \mathrm{~kJ} / \mathrm{mol}$. However, the formation of the $\eta^{2}$-cyclopropene intermediate is about thermoneutral for $\mathrm{Zr}$ and $\mathrm{Nb}(\Delta \mathrm{G}=7$ and $4 \mathrm{~kJ} / \mathrm{mol}$, respectively) while it is strongly endergonic for $\mathrm{W}$, indicating a process kinetically but also thermodynamically favourable for $\mathrm{Zr}$ and $\mathrm{Nb}$ complexes. A more significant difference appears for the activation barrier of the ring opening pathway which increases from $123(\mathrm{~W})$ to $151(\mathrm{Zr})$ and $177(\mathrm{Nb})$ $\mathrm{kJ} / \mathrm{mol}$. These results emphasize that the activation barriers for ring opening in the $\mathrm{Zr}$ and $\mathrm{Nb}$ complexes are high in energy, prohibiting such a process. Geometrical features at the TS indicate that the $\mathrm{C} \beta-\mathrm{C} \beta$ ' and $\mathrm{C} \alpha-\mathrm{C} \beta$ bonds are less elongated for the $\mathrm{Zr}$ and $\mathrm{Nb}$ complexes than for the $W$ case $(2.192 / 1.610 \AA$ for $Z r, 2.121 / 1.592 \AA$ for $N b$ versus $2.218 / 1.637 \AA$ for $W$, respectively). This is corroborated by a decreasing participation of the metal in the $\sigma_{\mathrm{C}_{\alpha} \mathrm{C} \beta} \mathrm{NLMO}$ from $12.1 \%$ for $\mathrm{W}$ to $6-7 \%$ for $\mathrm{Zr}$ and $\mathrm{Nb}$ (Table S2, Supporting Information). Consistent with these results, the CC-agostic interaction in the cyclopropyl complex (see LUMO plot, Figure S27, Supporting Information) is weaker for group 4 and 5 metals than for group 6 metal (C $\alpha$ $\mathrm{C} \beta$ bond: $1.554 \AA$ for $\mathrm{W}$ versus $1.542 \AA$ for $\mathrm{Zr}$ and $1.533 \AA$ for $\mathrm{Nb}$; see NLMO in Table S1), pointing out that the activation of the $\sigma_{C_{\alpha} C_{\beta}}$ bond in the reactant assists the cleavage of the $C \beta$ $\mathrm{C} \beta$ ' bond and governs the feasibility of the ring opening process.

The computational results show that $\left[\mathrm{Cp}{ }^{*} \mathrm{~W}(\mathrm{NO})\left(c-\mathrm{C}_{3} \mathrm{H}_{5}\right)\left(\mathrm{CH}_{2} \mathrm{SiMe}_{3}\right)\right]$ preferentially affords the thermodynamic product, the allyl complex, through a ring opening mechanism rather than the $\eta^{2}$-cyclopropene intermediate, as observed for $\mathrm{Zr}$ and $\mathrm{Nb}$. This comes from an accessible ring opening activation barrier combined with strong endergonicity for the competitive $\beta-\mathrm{H}$ abstraction process. The feasibility of the ring opening seems correlated to the energetic position of the LUMO of a rotamer $2-\mathbf{S i M e}_{3}{ }^{\text {nonago }}$ in which no $\alpha$-CC agostic distortion is present. In 2-SiMe ${ }^{\text {nonago }}$ the LUMO is significantly more energetically accessible (Figure S28, Supporting Information) than that in the analogous rotamers of $\left[\mathrm{Cp}_{2} \mathrm{Zr}\left(c-\mathrm{C}_{3} \mathrm{H}_{5}\right)_{2}\right]$ and $\left[\mathrm{Tp}^{\mathrm{Me} 2 \mathrm{Nb}}\left(c-\mathrm{C}_{3} \mathrm{H}_{5}\right)\left(\mathrm{CH}_{3}\right)(\mathrm{MeCCMe})\right]$. Consequently, the LUMO more easily interacts with the $\mathrm{C} \alpha-\mathrm{C} \beta$ bonds of the cyclopropyl ligand in the tungsten complex, favouring the cleavage of the $C \beta-C \beta$ ' bond.

\section{Conclusions}

Contrary to high oxidation state early transition alkyl cyclopropyl complexes, cyclopropyl complexes of tungsten of the type $\left[\mathrm{Cp}{ }^{*} \mathrm{~W}(\mathrm{NO})\left(c-\mathrm{C}_{3} \mathrm{H}_{5}\right)\left(\mathrm{CH}_{2} \mathrm{R}\right)\right]$ do not eliminate an hydrocarbon to yield unsaturated $\eta^{2}$-cyclopropene derivatives. Instead the cyclopropyl group readily ring opens to yield $\eta^{3}$-allyl derivatives $\left[\mathrm{Cp}{ }^{*} \mathrm{~W}(\mathrm{NO})\left(\eta^{3}-\mathrm{C}_{3} \mathrm{H}_{5}\right)\left(\mathrm{CH}_{2} \mathrm{R}\right)\right]$ in a manner reminiscent of that observed for unsaturated late transition metals. Computational studies 
show that both ring-opening and $\beta-\mathrm{H}$ abstraction are kinetically accessible for tungsten complexes, and that the process leading to the thermodynamic product, ring-opening takes place. The energetic accessibility and the nature of the LUMO of $\left[\mathrm{Cp}{ }^{*} \mathrm{~W}(\mathrm{NO})\left(\eta^{3}-\mathrm{C}_{3} \mathrm{H}_{5}\right)\left(\mathrm{CH}_{2} \mathrm{R}\right)\right]$ favours distal $\mathrm{CC}$ bond cleavage.

\section{Acknowledgments}

We thank the Agence Nationale de la Recherche for support of this work (ANR project "RICH", contract ANR-14-CE06-0012-01). The "Direction du Numérique" of the Université de Pau et des Pays de l'Adour, MCIA (Mésocentre de Calcul Intensif Aquitain) and CINES under allocation A005080045 made by Grand Equipement National de Calcul Intensif (GENCI) are acknowledged for computational facilities.

Keywords: allyl ligands • cyclopropyl ligands • tungsten $•$ DFT calculations $\bullet$ ring opening

\section{Experimental Section}

All experiments were carried out under a dry argon atmosphere using Schlenk line or glovebox (JACOMEX GP Concept; $\left[\mathrm{O}_{2}\right]<0.5 \mathrm{ppm},\left[\mathrm{H}_{2} \mathrm{O}\right]<0.5 \mathrm{ppm}$ ) techniques. Pentane, dichloromethane, and THF were passed through activated alumina columns under argon, and degassed by 3 freeze-pump-thaw cycles. 1,4-Dioxane (anhydrous, 99.8\%) and deuterated NMR solvents $\left(\mathrm{C}_{6} \mathrm{D}_{6}\right.$, THF- $\left.d_{8}\right)$ were degassed by three freeze-pump-thaw cycles, dried over molecular sieves, and stored under argon. The tungsten complexes $\left[\mathrm{Cp}{ }^{*} \mathrm{~W}(\mathrm{NO}) \mathrm{Cl}_{2}\right]^{\left[{ }^{[35]}\right.}$ $\left[\mathrm{Cp}{ }^{*} \mathrm{~W}(\mathrm{NO})\left(\mathrm{CH}_{2} \mathrm{SiMe}_{3}\right) \mathrm{Cl}\right]$ 1-SiMe $3,{ }^{[30]}\left[\mathrm{Cp}{ }^{*} \mathrm{~W}(\mathrm{NO})\left(\mathrm{CH}_{2} \mathrm{Ph}\right) \mathrm{Cl}\right]$ 1-Ph, ${ }^{[31]}$ and [Cp*W(NO) $\left(\mathrm{CH}_{2}-t-\right.$

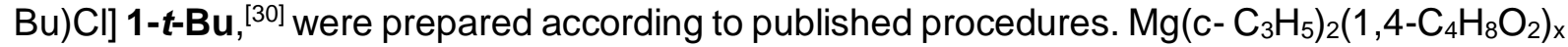
was prepared according to the published procedure, ${ }^{[36]}$ via the addition of 1,4-dioxane to the Grignard reagent $\mathrm{Mg}\left(c-\mathrm{C}_{3} \mathrm{H}_{5}\right) \mathrm{Br}$ (prepared from bromocyclopropane and $\mathrm{Mg}$ turnings in diethyl ether); the resultant bis(alkyl)magnesium reagent was titrated with $2-\mathrm{BuOH}$ (using a 1,10phenanthroline indicator) to determine its formula weight. ${ }^{1} \mathrm{H}$ and ${ }^{13} \mathrm{C}$ NMR spectra were obtained on Bruker Avance 400 or Avance 500 spectrometers at $T=293 \mathrm{~K}$ unless otherwise stated. Chemical shifts are reported in parts per million $(\mathrm{ppm})$ downfield from tetramethylsilane and are referenced to the residual solvent resonance as the internal standard: $C_{6} D_{6}=\delta 7.16$ $\left({ }^{1} \mathrm{H}\right), 128.06\left({ }^{13} \mathrm{C}\right)$; THF- $d_{8}=\delta 1.72\left({ }^{1} \mathrm{H}\right), 25.31\left({ }^{13} \mathrm{C}\right)$. For ${ }^{13} \mathrm{C}\left\{{ }^{1} \mathrm{H}\right\}$ gated NMR spectra, only pertinent $J_{\mathrm{CH}}$ are quoted. When necessary, assignments were made according to $2 \mathrm{D} H \mathrm{HQC}$ and HMBC spectra. FT-IR spectra were obtained on a PerkinElmer Spectrum Two spectrometer, and are reported in wavenumbers $\left(\mathrm{cm}^{-1}\right)$ with $(\mathrm{s})$ indicating strong absorption. Elemental analyses were obtained from the Analytical Service of our laboratory; results are the average of two independent measurements.

Generation of cyclopropyl complexes 2-R ( $\left.R=\mathrm{SiMe}_{3}, \mathrm{Ph}, \boldsymbol{t}-\mathrm{Bu}\right)$. Each complex 2$\mathbf{R}$ was prepared from the corresponding alkylchloro complex 1-R in a similar fashion. The detailed procedure for $\mathbf{2}-\mathrm{SiMe}_{3}$ is given below.

2-SiMe $:$ In the glove box, a $10 \mathrm{~mL}$ vial was charged with 1-SiMe 3 (35 mg, $0.074 \mathrm{mmol}$ ) and $0.8 \mathrm{~mL} \mathrm{THF-} d_{8}$, and cooled in the freezer at $\square 40{ }^{\circ} \mathrm{C}$ for $1 \mathrm{~h}$. Solid $\mathrm{Mg}\left(\mathrm{c}-\mathrm{C}_{3} \mathrm{H}_{5}\right)_{2}\left(1,4-\mathrm{C}_{4} \mathrm{H}_{8} \mathrm{O}_{2}\right)_{x}$ (titer $190 \mathrm{~g} / \mathrm{mol}, 7.1 \mathrm{mg}, 0.038 \mathrm{mmol}$ ) was added to this solution and the mixture was shaken vigorously, which resulted in an immediate colour change from indigo to red-purple. This solution was transferred to a J. Young valve NMR tube for immediate ( $<15 \mathrm{~min})$ spectroscopic analysis. 2-SiMe 3 could not be isolated as it rearranged to $3-\mathrm{SiMe}_{3}$ upon work-up. ${ }^{1} \mathrm{H}$ NMR $\left(400.2 \mathrm{MHz}, \mathrm{THF}-d_{8}\right): \delta 1.98\left(1 \mathrm{H}, \mathrm{m}, \alpha-c-\mathrm{C}_{3} H_{5}\right), 1.91\left(15 \mathrm{H}, \mathrm{s}, \mathrm{C}_{5} \mathrm{Me}_{5}\right), 1.80-1.65(3 \mathrm{H}$, 
overlapping $\left.\left.\mathrm{m}, \beta-c-\mathrm{C}_{3} \mathrm{H}_{5}\right), 1.31\left(1 \mathrm{H}, \mathrm{d},{ }^{2} \mathrm{~J}_{\mathrm{HH}}=12 \mathrm{~Hz}, \mathrm{CH}_{a} \mathrm{H}_{\mathrm{b}} \mathrm{SiMe}\right)_{3}\right), 0.55\left(1 \mathrm{H}, \mathrm{m}, \beta-c-\mathrm{C}_{3} \mathrm{H}_{5}\right)$, $\left.0.09\left(9 \mathrm{H}, \mathrm{s}, \mathrm{CH}_{2} \mathrm{SiMe}\right)_{3}\right),-1.44\left(1 \mathrm{H}, \mathrm{d},{ }^{2} \mathrm{~J}_{\mathrm{HH}}=12 \mathrm{~Hz}, \mathrm{CH}_{\mathrm{a}} \mathrm{H}_{b} \mathrm{SiMe}_{3}\right) .{ }^{13} \mathrm{C}\left\{{ }^{1} \mathrm{H}\right\}$ gated NMR $(100.6$ $\left.\mathrm{MHz}, \mathrm{THF}-\mathrm{d}_{8}\right): \delta 110.4\left(C_{5} \mathrm{Me}_{5}\right), 65.0\left(\mathrm{~d},{ }^{1} \mathrm{~J}_{\mathrm{CH}}=145 \mathrm{~Hz} ;{ }^{1} J_{\mathrm{WC}}=123 \mathrm{~Hz}, \mathrm{C \alpha}\right), 51.4\left(\mathrm{dd},{ }^{1} \mathrm{~J}_{\mathrm{CH}}=\right.$ 117, $99 \mathrm{~Hz}, \mathrm{CH}_{2} \mathrm{SiMe}_{3}$ ), 15.1 (dd, $\left.{ }^{1} J_{\mathrm{CH}}=167 \mathrm{~Hz}, 158 \mathrm{~Hz}, C \beta\right), 10.2\left(\mathrm{C}_{5} \mathrm{Me}_{5}\right), 9.7$ (dd, ${ }^{1} \mathrm{~J}_{\mathrm{CH}}=$ $\left.163 \mathrm{~Hz}, 162 \mathrm{~Hz}, C \beta^{\prime}\right), 3.1\left(\mathrm{CH}_{2} \mathrm{SiMe}_{3}\right)$. IR (THF) v/cm ${ }^{-1}: 1572$ (s, v $\left.v_{\mathrm{NO}}\right)$.

2-Ph. Colour change from orange (1-Ph) to red. ${ }^{1} \mathrm{H}$ NMR $\left(500.3 \mathrm{MHz}, \mathrm{THF}-\mathrm{d}_{8}, 243 \mathrm{~K}\right)$ : $\delta 7.58\left(1 \mathrm{H}, \mathrm{t}, J_{\mathrm{HH}}=8 \mathrm{~Hz}, p-\mathrm{C}_{6} H_{5}\right), 7.09\left(2 \mathrm{H}, \mathrm{t}, J_{\mathrm{HH}}=8 \mathrm{~Hz}, m-\mathrm{C}_{6} H_{5}\right), 6.84\left(2 \mathrm{H}, \mathrm{d}, J_{\mathrm{HH}}=8 \mathrm{~Hz}, o^{-}\right.$ $\left.\mathrm{C}_{6} \mathrm{H}_{5}\right), 3.17\left(1 \mathrm{H}, \mathrm{d},{ }^{2} \mathrm{~J}_{\mathrm{HH}}=6 \mathrm{~Hz}, \mathrm{CH}_{a} \mathrm{H}_{\mathrm{b}} \mathrm{Ph}\right), 1.93\left(15 \mathrm{H}, \mathrm{s}, \mathrm{C}_{5} \mathrm{Me}_{5}\right), 1.83\left(1 \mathrm{H}, \mathrm{d},{ }^{2} J_{\mathrm{HH}}=6 \mathrm{~Hz}\right.$, $\left.\mathrm{CH}_{\mathrm{a}} \mathrm{H}_{b} \mathrm{Ph}\right), 0.78\left(1 \mathrm{H}, \mathrm{m}, \beta-c-\mathrm{C}_{3} \mathrm{H}_{5}\right), 0.58\left(1 \mathrm{H}, \mathrm{m}, \beta-c-\mathrm{C}_{3} \mathrm{H}_{5}\right), 0.50\left(1 \mathrm{H}, \mathrm{m}, \beta-c-\mathrm{C}_{3} \mathrm{H}_{5}\right), 0.28(1 \mathrm{H}$, $\left.\mathrm{m}, \beta-c-\mathrm{C}_{3} H_{5}\right),-0.05\left(1 \mathrm{H}, \mathrm{m}, \alpha-c-\mathrm{C}_{3} H_{5}\right) .{ }^{13} \mathrm{C}\left\{{ }^{1} \mathrm{H}\right\}$ gated NMR $\left(125.8 \mathrm{MHz}\right.$, THF- $\left.d_{8}\right): \delta 133.91(\mathrm{~m}-$ $\left.C_{6} \mathrm{H}_{5}\right), 131.31\left(p-C_{6} \mathrm{H}_{5}\right), 130.50\left(o-\mathrm{C}_{6} \mathrm{H}_{5}\right), 118.51$ (s, ipso- $\left.C_{6} \mathrm{H}_{5}\right), 108.23\left(C_{5} \mathrm{Me}_{5}\right), 46.80$ (pt, $\left.{ }^{1} J_{\mathrm{CH}}=142 \mathrm{~Hz} ;{ }^{1} J_{\mathrm{CW}}=51 \mathrm{~Hz}, \mathrm{CH}_{2} \mathrm{Ph}\right), 26.62\left(\mathrm{~d},{ }^{1} \mathrm{~J}_{\mathrm{CH}}=146 \mathrm{~Hz} ;{ }^{1} J_{\mathrm{CW}}=123 \mathrm{~Hz}, \alpha-C_{-} C_{3} \mathrm{H}_{5}\right), 12.38$ (dd, $\left.{ }^{1} J_{\mathrm{CH}}=156,164 \mathrm{~Hz}, \beta-c-C_{3} \mathrm{H}_{5}\right), 10.27\left(\mathrm{C}_{5} M_{5}\right), 8.74\left(\mathrm{brt},{ }^{1} J_{\mathrm{CH}}=158 \mathrm{~Hz}, \beta{ }^{\prime}-c^{-}-C_{3} \mathrm{H}_{5}\right.$ ). IR (THF) $v / \mathrm{cm}^{-1}: 1572\left(\mathrm{~s}, \mathrm{v}_{\mathrm{NO}}\right)$.

2-t-Bu. Colour change from purple-red (1-t-Bu) to dark red. ${ }^{1} \mathrm{H}$ NMR $(400.2 \mathrm{MHz}$, THF$\left.d_{8}\right): \delta 3.18\left(1 \mathrm{H}, \mathrm{d},{ }^{2} \mathrm{~J}_{\mathrm{HH}}=13 \mathrm{~Hz}, \mathrm{CH}_{\mathrm{a}} \mathrm{H}_{\mathrm{b}} \mathrm{CMe}_{3}\right), 1.91\left(15 \mathrm{H}, \mathrm{s}, \mathrm{C}_{5} \mathrm{Me}_{5}\right), 1.89$ (obscured $\mathrm{m}, 1 \mathrm{H}$, $\left.\beta-c-\mathrm{C}_{3} H_{5}\right), 1.77\left(1 \mathrm{H}, \mathrm{m}, \beta-c-\mathrm{C}_{3} H_{5}\right), 1.61-1.57$ (overlapping, $2 \mathrm{H}, \mathrm{m}, \alpha-$ and $\left.\beta-c-\mathrm{C}_{3} \mathrm{H}_{5}\right), 1.12(9$ $\left.\mathrm{H}, \mathrm{s}, \mathrm{CH}_{2} \mathrm{CMe}_{3}\right), 0.72\left(1 \mathrm{H}, \mathrm{m}, \beta-c-\mathrm{C}_{3} \mathrm{H}_{5}\right),-1.52\left(1 \mathrm{H}, \mathrm{d},{ }^{2} \mathrm{~J}_{\mathrm{HH}}=13 \mathrm{~Hz}, J_{\mathrm{WH}}=11 \mathrm{~Hz}, \mathrm{CH}_{\mathrm{a}} \mathrm{H}_{b} \mathrm{CMe}_{3}\right)$. ${ }^{13} \mathrm{C}\left\{{ }^{1} \mathrm{H}\right\}$ gated NMR $\left(100.6 \mathrm{MHz}, \mathrm{THF}-d_{8}\right): \delta 110.2\left(C_{5} \mathrm{Me}_{5}\right), 99.8\left(\mathrm{t},{ }^{1} J_{\mathrm{CH}}=128 \mathrm{~Hz},{ }^{1} J_{\mathrm{WC}}=96 \mathrm{~Hz}\right.$, $\left.\mathrm{CH}_{2} \mathrm{CMe}_{3}\right), 55.7\left(\mathrm{~d},{ }^{1} \mathrm{~J}_{\mathrm{CH}}=145 \mathrm{~Hz},{ }^{1} J_{\mathrm{WC}}=128 \mathrm{~Hz}, \alpha-\mathrm{C}-\mathrm{C}_{3} \mathrm{H}_{5}\right), 39.6\left(\mathrm{CH}_{2} \mathrm{CMe}_{3}\right), 34.6\left(\mathrm{q},{ }^{1} \mathrm{~J}_{\mathrm{CH}}=\right.$ $124 \mathrm{~Hz}, \mathrm{CH}_{2} \mathrm{CMe}$ ), 13.7 (pt, $\left.{ }^{1} \mathrm{~J}_{\mathrm{CH}}=162 \mathrm{~Hz}, \beta-c-C_{3} \mathrm{H}_{5}\right), 12.1$ (pt, $\left.{ }^{1} \mathrm{~J}_{\mathrm{CH}}=160 \mathrm{~Hz}, \beta-C-C_{3} \mathrm{H}_{5}\right), 10.2$ $\left(\mathrm{C}_{5} \mathrm{Me}_{5}\right)$. IR (THF) $v / \mathrm{cm}^{-1}: 1564\left(\mathrm{~s}, v_{\mathrm{NO}}\right)$.

Synthesis of allyl complexes 3-R $\left(\mathbf{R}=\mathrm{SiMe}_{3}, \mathbf{P h}, \boldsymbol{t}\right.$-Bu). Each complex 3-R was prepared from the corresponding alkylchloro complex 1-R in a similar fashion. The detailed procedure for 3-SiMe 3 is given below.

3-SiMe. In the glove box, a $250 \mathrm{~mL}$ Schlenk flask was charged with a magnetic bar stir, 1-SiMe 3 (295 mg, $0.625 \mathrm{mmol})$, and THF $(10 \mathrm{~mL})$. This flask was connected to the Schlenk line, submerged in an acetone/liquid $\mathrm{N}_{2}$ bath $\left(-35^{\circ} \mathrm{C}\right)$ and stirred magnetically. A solution of $\mathrm{Mg}\left(c-\mathrm{C}_{3} \mathrm{H}_{5}\right)_{2} \cdot x\left(1,4-\mathrm{C}_{4} \mathrm{H}_{8} \mathrm{O}_{2}\right)$ (titer of $\left.190 \mathrm{~g} / \mathrm{mol}, 60 \mathrm{mg}, 0.312 \mathrm{mmol}\right)$ in THF $(10 \mathrm{~mL})$ was added via cannula, and the resulting red-purple solution was allowed to warm to room temperature (approximately $\sim 1 \mathrm{~h}$ ). Subsequent removal of the solvent in vacuo afforded a dark yellowbrown residue, which was extracted with dichloromethane $(20 \mathrm{~mL})$ and transferred to a vial via a filter cannula in the glove box. The yellow-brown filtrate was concentrated in vacuo $(10 \mathrm{~mL})$, layered with pentane $(5 \mathrm{~mL})$, and stored in the glove box freezer at $-40^{\circ} \mathrm{C}$. After several days, the resulting yellow-brown crystals were collected on a sintered glass frit, washed with a minimum amount of cold pentane, and dried in vacuo. Yield: $189 \mathrm{mg}(0.388 \mathrm{mmol}, 62 \%) .{ }^{1} \mathrm{H}$ $\operatorname{NMR}\left(400.2 \mathrm{MHz}, \mathrm{C}_{6} \mathrm{D}_{6}\right): \delta 5.34\left(1 \mathrm{H}, \mathrm{s}, \beta-\mathrm{CH}_{2} \mathrm{CHCH}_{2}\right), 3.49\left(1 \mathrm{H}, \mathrm{br} \mathrm{m}, \gamma-\mathrm{CH}_{2} \mathrm{CHCH}_{2}\right), 2.42(1$ $\mathrm{H}$, br m, $\left.\alpha-\mathrm{CH}_{2} \mathrm{CHCH}_{2}\right), 1.90\left(1 \mathrm{H}\right.$, br m, $\left.\gamma-\mathrm{CH}_{2} \mathrm{CHCH}_{2}\right), 1.48\left(15 \mathrm{H}, \mathrm{s}, \mathrm{C}_{5} \mathrm{Me}_{5}\right), 0.54(1 \mathrm{H}, \mathrm{br} \mathrm{m}$, $\left.\alpha-\mathrm{CH}_{2} \mathrm{CHCH}_{2}\right), 0.36\left(9 \mathrm{H}, \mathrm{s}, \mathrm{CH}_{2} \mathrm{SiMe}_{3}\right),-0.05\left(1 \mathrm{H}, \mathrm{d},{ }^{2} \mathrm{~J}_{\mathrm{HH}}=12 \mathrm{~Hz}, \mathrm{CH}_{\mathrm{a}} \mathrm{H}_{\mathrm{b}} \mathrm{SiMe}_{3}\right),-0.57(1$ $\left.\mathrm{H}, \mathrm{d},{ }^{2} \mathrm{JHH}_{\mathrm{HH}}=12 \mathrm{~Hz}, \mathrm{CH}_{\mathrm{a}} \mathrm{H}_{b} \mathrm{SiMe}_{3}\right) .{ }^{1} \mathrm{H}$ NMR $\left(400.2 \mathrm{MHz}, \mathrm{THF}-d_{8}\right): \delta 5.19(1 \mathrm{H}, \mathrm{br} \mathrm{m}, \beta-$ $\left.\mathrm{CH}_{2} \mathrm{CHCH}_{2}\right), 3.52\left(1 \mathrm{H}\right.$, br m, $\left.\gamma-\mathrm{CH}_{2} \mathrm{CHCH}_{2}\right), 2.29\left(1 \mathrm{H}, \mathrm{br} \mathrm{m}, \alpha-\mathrm{CH}_{2} \mathrm{CHCH}_{2}\right), 2.19(1 \mathrm{H}, \mathrm{br} \mathrm{m}$, $\left.\gamma-\mathrm{CH}_{2} \mathrm{CHCH}_{2}\right), 1.83\left(15 \mathrm{H}, \mathrm{s}, \mathrm{C}_{5} \mathrm{Me}_{5}\right), 0.74\left(1 \mathrm{H}\right.$, br m, $\left.\alpha-\mathrm{CH}_{2} \mathrm{CHCH}_{2}\right),-0.08\left(9 \mathrm{H}, \mathrm{s}, \mathrm{CH}_{2} \mathrm{SiMe} 3\right)$, $-0.10\left(1 \mathrm{H}, \mathrm{d},{ }^{2} \mathrm{~J}_{\mathrm{HH}}=12 \mathrm{~Hz}, \mathrm{CH}_{\mathrm{a}} \mathrm{H}_{\mathrm{b}} \mathrm{SiMe}\right),-0.70\left(1 \mathrm{H}, \mathrm{d},{ }^{2} \mathrm{~J}_{\mathrm{HH}}=12 \mathrm{~Hz}, \mathrm{CH}_{\mathrm{a}} \mathrm{H}_{b} \mathrm{SiMe}_{3}\right) .{ }^{13} \mathrm{C}\left\{{ }^{1} \mathrm{H}\right\}$ gated NMR (100.6 MHz, $\left.\mathrm{C}_{6} \mathrm{D}_{6}\right): \delta 111.6\left(\mathrm{~d},{ }^{1} \mathrm{~J}_{\mathrm{CH}}=164 \mathrm{~Hz}, \beta-\mathrm{CH}_{2} \mathrm{CHCH}_{2}\right), 106.5\left(C_{5} \mathrm{Me}_{5}\right), 79.2$ $\left(\mathrm{t},{ }^{1} J_{\mathrm{CH}}=156 \mathrm{~Hz}, \gamma-\mathrm{CH}_{2} \mathrm{CHCH}_{2}\right), 40.9\left(\mathrm{t},{ }^{1} \mathrm{~J}_{\mathrm{CH}}=154 \mathrm{~Hz},{ }^{1} J_{\mathrm{WC}}=76 \mathrm{~Hz}, \alpha-\mathrm{CH}_{2} \mathrm{CHCH}_{2}\right), 10.0$ $\left(\mathrm{C}_{5} \mathrm{Me}_{5}\right), 3.6\left(\mathrm{CH}_{2} \mathrm{SiMe}_{3}\right),-7.4\left(\mathrm{pt},{ }^{1} \mathrm{~J}_{\mathrm{CH}}=116 \mathrm{~Hz},{ }^{1} J_{\mathrm{WC}}=56 \mathrm{~Hz}, \mathrm{CH}_{2} \mathrm{SiMe}_{3}\right) \cdot{ }^{13} \mathrm{C}\left\{{ }^{1} \mathrm{H}\right\}$ gated NMR $\left(100.6 \mathrm{MHz}, \mathrm{THF}-d_{8}\right): \delta 112.2\left(\mathrm{~d},{ }^{1} J_{\mathrm{CH}}=161 \mathrm{~Hz}, \beta-\mathrm{CH}_{2} \mathrm{CHCH}_{2}\right), 107.3\left(C_{5} \mathrm{Me}_{5}\right), 79.4$ (pt, ${ }^{1} J_{\mathrm{CH}}$ $\left.=158 \mathrm{~Hz}, \gamma-\mathrm{CH}_{2} \mathrm{CHCH}_{2}\right), 40.8\left(\mathrm{pt},{ }^{1} \mathrm{~J}_{\mathrm{CH}}=157 \mathrm{~Hz},{ }^{1} J_{\mathrm{Wc}}=56 \mathrm{~Hz}, \alpha-\mathrm{CH}_{2} \mathrm{CHCH}_{2}\right), 10.3\left(\mathrm{C}_{5} \mathrm{Me}_{5}\right)$, $3.5\left(\mathrm{CH}_{2} \mathrm{SiMe}_{3}\right),-7.6\left(\mathrm{dd},{ }^{1} \mathrm{~J}_{\mathrm{CH}}=120,108 \mathrm{~Hz},{ }^{1} J_{\mathrm{Wc}}=85 \mathrm{~Hz}, \mathrm{CH}_{2} \mathrm{SiMe}_{3}\right) . \mathrm{IR}(\mathrm{THF}) v / \mathrm{cm}^{-1}: 1584$ 
(s, vNo). Elem. Anal. calcd. for $\mathrm{C}_{17} \mathrm{H}_{31} \mathrm{SiNOW}$ : C, 42.77; H, 6.55; N, 2.93. Found: C, 42.40; $\mathrm{H}$, $6.22 ; \mathrm{N}, 2.58$.

3-Ph. From 1-Ph $(350 \mathrm{mg}, 0.735 \mathrm{mmol})$ and $\mathrm{Mg}\left(c-\mathrm{C}_{3} \mathrm{H}_{5}\right)_{2} \cdot x\left(1,4-\mathrm{C}_{4} \mathrm{H}_{8} \mathrm{O}_{2}\right)$ (titer of 190 $\mathrm{g} / \mathrm{mol}, 70 \mathrm{mg}, 0.367 \mathrm{mmol}$ ) orange brown crystals (230 mg, $0.474 \mathrm{mmol}, 65 \%$ ) were obtained. ${ }^{1} \mathrm{H}$ NMR $\left(400.2 \mathrm{MHz}, \mathrm{C}_{6} \mathrm{D}_{6}\right): \delta 7.48\left(2 \mathrm{H}, \mathrm{d}, J=7.6 \mathrm{~Hz}, o_{-} \mathrm{C}_{6} \mathrm{H}_{5}\right), 7.28(2 \mathrm{H}, \mathrm{t}, J=7.6 \mathrm{~Hz}, m-$ $\left.\mathrm{C}_{6} \mathrm{H}_{5}\right), 6.98\left(1 \mathrm{H}, \mathrm{t}, J=7.6 \mathrm{~Hz}, p-\mathrm{C}_{6} H_{5}\right), 4.61\left(1 \mathrm{H}, \mathrm{m}\right.$, ddt, $\left.J=13.8,9.9,6.9 \mathrm{~Hz}, \beta-\mathrm{CH}_{2} \mathrm{CHCH}_{2}\right)$, $3.55\left(1 \mathrm{H}, \mathrm{dd}, J=7.0,3.6 \mathrm{~Hz}, \gamma-\mathrm{CH}_{2} \mathrm{CHCH}_{2}\right), 2.84\left(1 \mathrm{H}, \mathrm{d}, J=9.4 \mathrm{~Hz}, \mathrm{CH}_{\mathrm{a}} \mathrm{H}_{\mathrm{b}} \mathrm{Ph}\right), 2.34(1 \mathrm{H}, \mathrm{m}$, ddd, $\left.J=6.3,3.8,2.1 \mathrm{~Hz}, \alpha-\mathrm{CH}_{2} \mathrm{CHCH}_{2}\right), 1.97\left(1 \mathrm{H}, \mathrm{d},{ }^{2} J_{\mathrm{HH}}=9.4 \mathrm{~Hz}, \mathrm{CH}_{\mathrm{a}} H_{b} \mathrm{Ph}\right), 1.81(1 \mathrm{H}$, dd, $\left.J=14.0,1.5 \mathrm{~Hz}, \gamma-\mathrm{CH}_{2} \mathrm{CHCH}_{2}\right), 1.48\left(15 \mathrm{H}, \mathrm{s}, \mathrm{C}_{5} M \mathrm{Me}_{5}\right), 0.61(1 \mathrm{H}, \mathrm{br} \mathrm{d}, J=10.0 \mathrm{~Hz}, \alpha-$ $\left.\mathrm{CH}_{2} \mathrm{CHCH}_{2}\right) .{ }^{1} \mathrm{H}$ NMR $\left(400.2 \mathrm{MHz}\right.$, THF- $\left.d_{8}\right): \delta 7.03\left(2 \mathrm{H}\right.$, br d, $\left.J_{\mathrm{HH}}=7.9 \mathrm{~Hz}, 0-\mathrm{C}_{6} \mathrm{H}_{5}\right), 6.97(2 \mathrm{H}$, br t, $\left.J_{\mathrm{HH}}=7.7 \mathrm{~Hz}, m-\mathrm{C}_{6} H_{5}\right), 6.73\left(1 \mathrm{H}, \mathrm{brt}, J_{\mathrm{HH}}=7.2 \mathrm{~Hz}, p-\mathrm{C}_{6} H_{5}\right), 4.39(1 \mathrm{H}, \mathrm{ddt}, J=13.8,9.9$, $\left.6.8 \mathrm{~Hz}, \beta-\mathrm{CH}_{2} \mathrm{CHCH}_{2}\right), 3.46\left(1 \mathrm{H}, \mathrm{dd}, J=7.0,3.6 \mathrm{~Hz}, \gamma-\mathrm{CH}_{2} \mathrm{CHCH}_{2}\right), 2.61\left(1 \mathrm{H}, \mathrm{d},{ }^{2} J_{\mathrm{HH}}=9.3\right.$ $\left.\mathrm{Hz}, \mathrm{CH}_{\mathrm{a}} \mathrm{H}_{\mathrm{b}} \mathrm{Ph}\right), 2.32\left(1 \mathrm{H}, \mathrm{m}, \mathrm{ddd}, J=6.2,3.5,2.0 \mathrm{~Hz}, \alpha-\mathrm{CH}_{2} \mathrm{CHCH}_{2}\right), 2.10\left(1 \mathrm{H}, \mathrm{dd},{ }^{2} J_{\mathrm{HH}}=14\right.$, $\left.1.5 \mathrm{~Hz}, \gamma-\mathrm{CH}_{2} \mathrm{CHCH}_{2}\right), 1.93\left(1 \mathrm{H}, \mathrm{d},{ }^{2} \mathrm{~J}_{\mathrm{HH}}=9.3 \mathrm{~Hz}, \mathrm{CH}_{\mathrm{a}} H_{b} \mathrm{Ph}\right), 1.89\left(15 \mathrm{H}, \mathrm{s}, \mathrm{C}_{5} M_{5}\right), 0.91(1 \mathrm{H}$, br d, ${ }^{2} J_{\mathrm{HH}}=9.8 \mathrm{~Hz}, \alpha-\mathrm{CH}_{2} \mathrm{CHCH}_{2}$ ). ${ }^{13} \mathrm{C}\left\{{ }^{1} \mathrm{H}\right\}$ gated NMR (100.6 MHz, $\left.\mathrm{C}_{6} \mathrm{D}_{6}\right): \delta 153.4$ (s, ipso$\left.C_{6} \mathrm{H}_{5}\right), 128.8\left(\mathrm{~d},{ }^{1} \mathrm{~J}_{\mathrm{CH}}=158 \mathrm{~Hz}, o_{-} C_{6} \mathrm{H}_{5}\right), 127.8\left(\mathrm{~d},{ }^{1} \mathrm{~J}_{\mathrm{CH}}=158 \mathrm{~Hz}, m-C_{6} \mathrm{H}_{5}\right), 123.1\left(\mathrm{~d},{ }^{1} \mathrm{~J}_{\mathrm{CH}}=158\right.$ $\left.\mathrm{Hz}, p-C_{6} \mathrm{H}_{5}\right), 107.8\left(\mathrm{~d},{ }^{1} J_{\mathrm{CH}}=162 \mathrm{~Hz}, \beta-\mathrm{CH}_{2} \mathrm{CHCH}_{2}\right), 106.1\left(C_{5} \mathrm{Me}_{5}\right), 81.3\left(\mathrm{pt},{ }^{1} J_{\mathrm{CH}}=157 \mathrm{~Hz}, \gamma-\right.$ $\left.\mathrm{CH}_{2} \mathrm{CHCH}_{2}\right), 42.4\left(\mathrm{pt},{ }^{1} J_{\mathrm{CH}}=153 \mathrm{~Hz},{ }^{1} J_{\mathrm{WC}}=24 \mathrm{~Hz}, \alpha-\mathrm{CH}_{2} \mathrm{CHCH}_{2}\right), 20.7\left(\mathrm{t},{ }^{1} J_{\mathrm{CH}}=127 \mathrm{~Hz},{ }^{1} J_{\mathrm{WC}}\right.$ $=74 \mathrm{~Hz}, \mathrm{CH}_{2} \mathrm{Ph}$ ), $9.8\left(\mathrm{C}_{5} \mathrm{Me}_{5}\right)$. IR (THF) v/cm ${ }^{-1}: 1589$ (s, $\left.v_{\mathrm{NO}}\right)$. Elem. Anal. calcd. for $\mathrm{C}_{20} \mathrm{H}_{27} \mathrm{NOW}: \mathrm{C}, 49.91 ; \mathrm{H}, 5.65 ; \mathrm{N}, 2.91$. Found: $\mathrm{C}, 42.35 ; \mathrm{H}, 5.44 ; \mathrm{N}, 2.73$.

3-t-Bu. From 1-t-Bu (170 mg, $0.37 \mathrm{mmol}$ ) and $\mathrm{Mg}\left(c-\mathrm{C}_{3} \mathrm{H}_{5}\right)_{2} \cdot x\left(1,4-\mathrm{C}_{4} \mathrm{H}_{8} \mathrm{O}_{2}\right.$ ) (titer of 190 $\mathrm{g} / \mathrm{mol}, 35.5 \mathrm{mg}, 0.18 \mathrm{mmol}$ ) an orange brown powder (55 mg, $0.12 \mathrm{mmol}, 32 \%$ ) was obtained. ${ }^{1} \mathrm{H}$ NMR $\left(400.2 \mathrm{MHz}, \mathrm{C}_{6} \mathrm{D}_{6}\right): \delta 5.19\left(1 \mathrm{H}, \mathrm{br} \mathrm{s}, \square-\mathrm{CH}_{2} \mathrm{CHCH}_{2}\right), 3.80\left(1 \mathrm{H}, \mathrm{br} \mathrm{s}, \gamma-\mathrm{CH}_{2} \mathrm{CHCH}_{2}\right)$, $2.40\left(1 \mathrm{H}\right.$, br s, $\left.\alpha-\mathrm{CH}_{2} \mathrm{CHCH}_{2}\right), 1.85\left(1 \mathrm{H}\right.$, br s, $\left.\gamma-\mathrm{CH}_{2} \mathrm{CHCH}_{2}\right), 1.68\left(1 \mathrm{H}, \mathrm{d},{ }^{2} J_{\mathrm{HH}}=12.5 \mathrm{~Hz}\right.$, $\left.\mathrm{CH}_{\mathrm{a}} \mathrm{H}_{\mathrm{b}} \mathrm{CMe}_{3}\right), 1.49\left(15 \mathrm{H}, \mathrm{s}, \mathrm{C}_{5} \mathrm{Me}_{5}\right), 1.31\left(9 \mathrm{H}, \mathrm{s}, \mathrm{CH}_{2} \mathrm{CMe}_{3}\right), 0.94\left(1 \mathrm{H}, \mathrm{d},{ }^{2} \mathrm{~J}_{\mathrm{HH}}=12.5 \mathrm{~Hz}\right.$, $\left.\mathrm{CH}_{a} \mathrm{H}_{b} \mathrm{CMe}_{3}\right), 0.49\left(1 \mathrm{H}\right.$, br m, allyl $\left.\alpha-\mathrm{CH}_{2} \mathrm{CHCH}_{2}\right) \cdot{ }^{13} \mathrm{C}\left\{{ }^{1} \mathrm{H}\right\}$ gated NMR $\left(100.6 \mathrm{MHz}, \mathrm{C}_{6} \mathrm{D}_{6}\right): \delta$ 112.1 (br d, $\left.{ }^{1} J_{\mathrm{CH}}=163 \mathrm{~Hz}, \beta-\mathrm{CH}_{2} \mathrm{CHCH}_{2}\right), 106.2\left(C_{5} \mathrm{Me}_{5}\right), 79.3$ (br pt, ${ }^{1} \mathrm{~J}_{\mathrm{CH}}=160 \mathrm{~Hz}, \gamma-$ $\left.\mathrm{CH}_{2} \mathrm{CHCH}_{2}\right), 40.3$ (br pt, ${ }^{1} \mathrm{~J}_{\mathrm{CH}}=155 \mathrm{~Hz}$, allyl $\left.\alpha-\mathrm{CH}_{2} \mathrm{CHCH}_{2}\right), 39.2\left(\mathrm{CH}_{2} \mathrm{CMe}_{3}\right), 34.5\left(\mathrm{CH}_{2} \mathrm{CMe}_{3}\right)$, $26.9\left(\mathrm{t},{ }^{1} J_{\mathrm{CH}}=121 \mathrm{~Hz},{ }^{1} J_{\mathrm{WC}}=84 \mathrm{~Hz}, \mathrm{CH}_{2} \mathrm{CMe}_{3}\right) 9.9\left(\mathrm{C}_{5} \mathrm{Me}_{5}\right)$. IR (THF) v/cm ${ }^{-1}: 1585$ (s, $\left.\mathrm{v}_{\mathrm{NO}}\right)$. Elem. Anal. calcd. for $\mathrm{C}_{18} \mathrm{H}_{31} \mathrm{~N}_{1} \mathrm{O}_{1} \mathrm{~W}_{1}$ : C, 46.87; $\mathrm{H}, 6.77 ; \mathrm{N}, 3.04$. Found: $\mathrm{C}, 46.88 ; \mathrm{H}, 6.72 ; \mathrm{N}$, 2.97.

\section{Kinetic Studies}

Experimental study. All kinetic studies for the rearrangement of 2-R to $\mathbf{3}-\mathbf{R}$ have been carried out following a similar protocol which is detailed herein for 2-SiMe $\mathbf{2}_{3}$. Kinetics for the rearrangement of $2-\mathrm{SiMe}_{3}$ were studied by ${ }^{1} \mathrm{H}$ NMR spectroscopy at five different initial concentrations $\left(\left[2-\mathrm{SiMe}_{3}\right]_{0}=0.0304,0.121,0.142,0.215,0.261 \mathrm{~mol} / \mathrm{L}\right)$. At $\left[2-\mathrm{SiMe}_{3}\right]_{0}=0.0121$ $\mathrm{mol} / \mathrm{L}$, experiments conducted on crude or filtered solutions gave identical rates. At [2-SiMe $]_{0}$ $=0.047 \mathrm{~mol} / \mathrm{L}$, experiments carried out at four different temperatures $(288,298,308$ and 318 $\mathrm{K})$ were used to extract activation parameters.

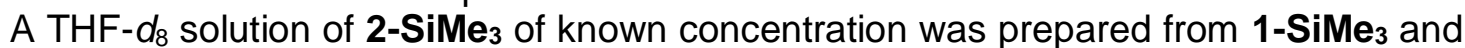
$\mathrm{Mg}\left(\mathrm{c}-\mathrm{C}_{3} \mathrm{H}_{5}\right)_{2} \cdot x\left(1,4-\mathrm{C}_{4} \mathrm{H}_{8} \mathrm{O}_{2}\right)$ as described in the Synthesis section. It was allowed to equilibrate thermally in the probe of the NMR spectrometer at the desired temperature before starting data

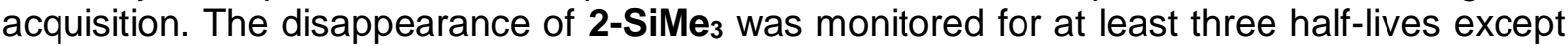

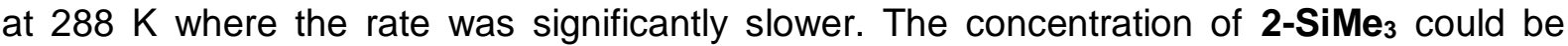
expressed as the integral measured for either the $\mathrm{C}_{5} \mathrm{Me}_{5}$ resonance $(\delta 1.91)$ or the $\mathrm{CH}_{2} \mathrm{SiMe}_{3}$ resonance $(\delta 0.09)$ in 2-SiMe , divided by the sum of that integral and the integral for the $\mathrm{C}_{5} \mathrm{Me}_{5}$ resonance $(\delta 1.83)$ or the $\mathrm{CH}_{2} \mathrm{SiMe}_{3}$ resonance $(\delta-0.08)$ in 3-SiMe 3 . These integrations were normalised to a benzene internal standard. The data were used to construct the plots of In[2- 
$\left.\mathrm{SiMe}_{3}\right]=f(t)$ which were found linear with similar slopes using either the $\mathrm{C}_{5} \mathrm{Me}_{5}$ or $\mathrm{CH}_{2} \mathrm{SiMe}_{3}$ resonance as shown in Figure 3.

Kinetic simulations. A homemade program SA was used to fit the kinetic data. The corresponding differential equations were integrated numerically using a semi-implicit RungeKutta method. The unknown parameters were fitted automatically using an iterative algorithm of the Powell type, designed to minimize the residual quadratic error $E=\Sigma j \sum i\left[c_{i j}-\mathrm{e}_{i j}\right]^{2} /(n M)$ where $c_{i j}$ and $e_{i j}$ are the computed and experimental values of concentrations, respectively, $n$ is the number of data points in a given run, and $N$ is the number of runs (three in this case).

\section{Computational section}

DFT calculations have been carried out with the PBE0 functional[ ${ }^{[37]}$ as implemented in Gaussian 09. ${ }^{38]}$ Tungsten, zirconium and niobium atoms were described with the relativistic electron core potential SDD and the associated basis set. ${ }^{[39]}$ They have been augmented by a set of $f$ polarisation functions. ${ }^{[40]}$ The $6-31 \mathrm{G}^{\star *}$ basis set was employed for all other atoms. Full optimisations for all stationary points, minima and transition state structures were performed. Frequency calculations were undertaken at the same level of theory than optimisation to confirm the nature of the stationary points, yielding one imaginary frequency for transition states (TS), corresponding to the expected process, and zero for minima. The connectivity of the transition states and their adjacent minima was confirmed by intrinsic reaction coordinate (IRC) calculations. ${ }^{[41,42]}$ In order to consider dispersion and solvent effects, single point (SP) calculations have also been carried out for the tungsten profile at the SMD ${ }^{[43]}$ (THF)-PBE0$\mathrm{D} 3 / \mathrm{SDD}+\mathrm{f}(\mathrm{W}), 6-311++\mathrm{G}^{* *}$ (other atoms) level of theory with Grimme's D3 dispersion corrections in the Becke-Johnson damping variant ${ }^{[4,45]}$ on the geometry optimised in the gas phase. Gibbs free energies were obtained by adding the electronic energy computed at the SMD(THF)-PBE0-D3 level and the thermal correction to Gibbs free energy computed at the PBE0 level in the gas phase. ${ }^{[46]}$ All energies presented correspond to free energies in the gas phase or in the solvent into brackets (SP calculations) and are given in $\mathrm{kJ} / \mathrm{mol}$. All reported Gibbs free energies $(\Delta G)$ in the gas phase were temperature corrected using unscaled density functional frequencies.

To further analyse the agostic interaction involved in reactants and transition states (TS), Natural Bond Orbital ${ }^{[47]}$ (NBO, version 5.9) ${ }^{[48]}$ analyses have been performed. Stabilising interactions $(\Delta \mathrm{E}(2)$ in $\mathrm{kJ} / \mathrm{mol})$, determined at the second order perturbation theory, have been computed to get insight on this donor-acceptor interaction. The Natural Localized Molecular Orbital (NLMO) associated to the $\sigma_{c c}$ orbital has also been determined.

\section{Crystallography}

Data for 3-Ph were collected at low temperature $(100 \mathrm{~K})$ on a Bruker APEX II diffractometer using a graphite-monochromated Mo-K $\alpha$ radiation $(\lambda=0.71073 \AA)$ and equipped with an Oxford Cryosystems Cryostream Cooler Device. The structure was solved by direct methods using SHELXS-97, ${ }^{[49]}$ and refined by means of least-squares procedures on a $\mathrm{F}^{2}$ with the aid of the program SHELXL2016 ${ }^{[49]}$ included in the software package WinGX version $1.63{ }^{[50]}$ All hydrogens atoms were placed geometrically, and refined by using a riding model. All non-hydrogens atoms were anisotropically refined, and in the last cycles of refinement a weighting scheme was used, where weights are calculated from the following formula: $w=1 /\left[\sigma^{2}\left(F o^{2}\right)+(a P)^{2}+b P\right]$ where $P=\left(F o^{2}+2 F c^{2}\right) / 3$. Drawing of the molecule was performed with the program ORTEP $32^{[51]}$ with $30 \%$ probability displacement ellipsoids for non-hydrogen atoms. Crystal data. $\mathrm{C}_{20} \mathrm{H}_{27} \mathrm{NOW}, \mathrm{M} 481.27$, orthorhombic, $a=8.8458$ (6), $b=13.2211$ (9), $c=$ 15.7081(11) $\AA, U=1837.1(2) \AA^{3}, T=100 \mathrm{~K}$, space group $P 2{ }_{1} 2_{1} 2_{1}, Z=4$, 44975 reflections measured (3762 independent, $\left.R_{\text {int }} 0.044\right), R$ (all data) $=0.013$, w $R$ (all data) $=0.0269$, Flack parameter $=-0.004(8)$. CCDC 1935773. 


\section{References:}

[1] S. L. Buchwald, R. B. Nielsen, Chem. Rev. 1988, 88, 1047-1058.

[2] J. Yin, W. M. Jones, Organometallics 1993, 12, 2013-2014.

[3] N. Romero, Q. Dufrois, L. Vendier, C. Dinoi, M. Etienne, Chem. - Eur. J. 2017, 23, 15766-15774.

[4] Y. Hu, N. Romero, C. Dinoi, L. Vendier, S. Mallet-Ladeira, J. E. McGrady, A. Locati, F. Maseras, M. Etienne, Organometallics 2014, 33, 7270-7278.

[5] P. Oulié, C. Dinoi, C. Li, A. Sournia-Saquet, K. Jacob, L. Vendier, M. Etienne, Organometallics 2017, 36, 5363.

[6] C. Boulho, L. Vendier, M. Etienne, A. Locati, F. Maseras, J. E. McGrady, Organometallics 2011, 30, 39994007.

[7] C. Boulho, P. Oulié, L. Vendier, M. Etienne, V. Pimienta, A. Locati, F. Bessac, F. Maseras, D. A. Pantazis, J. E. McGrady, J. Am. Chem. Soc. 2010, 132, 14239-14250.

[8] P. Oulie, C. Boulho, L. Vendier, Y. Coppel, M. Etienne, J. Am. Chem. Soc. 2006, 128, 15962-15963.

[9] C. Li, C. Dinoi, Y. Coppel, M. Etienne, J. Am. Chem. Soc. 2015, 137, 12450-12453.

[10] N. A. Petasis, E. I. Bzowej, Tetrahedron Lett. 1993, 34, 943-946.

[11] R. A. Baillie, P. Legzdins, Acc. Chem. Res. 2014, 47, 330-340.

[12] C. B. Pamplin, P. Legzdins, Acc. Chem. Res. 2003, 36, 223-233.

[13] R. A. Baillie, B. O. Patrick, P. Legzdins, D. C. Rosenfeld, Organometallics 2017, 36, $26-38$.

[14] R. A. Baillie, T. Tran, K. M. Lalonde, J. Y. K. Tsang, M. E. Thibault, B. O. Patrick, P. Legzdins, Organometallics 2012, 31, 1055-1067.

[15] R. A. Baillie, R. W. Y. Man, M. V. Shree, C. Chow, M. E. Thibault, W. S. McNeil, P. Legzdins, Organometallics 2011, 30, 6201-6217.

[16] T. Tran, C. Chow, A. C. Zimmerman, M. E. Thibault, W. S. McNeil, P. Legzdins, Organometallics 2011, 30 , $738-751$.

[17] J. Y. K. Tsang, M. S. A. Buschhaus, P. M. Graham, C. J. Semiao, S. P. Semproni, S. J. Kim, P. Legzdins, J. Am. Chem. Soc. 2008, 130, 3652-3663.

[18] J. Y. K. Tsang, M. S. A. Buschhaus, P. Legzdins, J. Am. Chem. Soc. 2007, 129, 5372-+.

[19] K. Wada, C. B. Pamplin, P. Legzdins, B. O. Patrick, I. Tsyba, R. Bau, J. Am. Chem. Soc. 2003, 125, 70357048.

[20] S. H. K. Ng, C. S. Adams, T. W. Hayton, P. Legzdins, B. O. Patrick, J. Am. Chem. Soc. 2003, 125, 1521015223.

[21] S. H. K. Ng, C. S. Adams, P. Legzdins, J. Am. Chem. Soc. 2002, 124, 9380-9381.

[22] J. D. Debad, P. Legzdins, S. A. Lumb, S. J. Rettig, R. J. Batchelor, F. W. B. Einstein, Organometallics 1999, 18, 3414-3428.

[23] P. Legzdins, S. A. Lumb, Organometallics 1997, 16, 1825-1827.

[24] J. D. Debad, P. Legzdins, S. A. Lumb, R. J. Batchelor, F. W. B. Einstein, J. Am. Chem. Soc. 1995, 117, 32883289.

[25] K. D. J. Parker, L. Vendier, M. Etienne, Organometallics 2018, 37, 1221-1224.

[26] N. J. Conti, D. J. Crowther, S. Tivakornpannarai, W. M. Jones, Organometallics 1990, 9, 175-184.

[27] Tatjana. Omrcen, N. J. Conti, W. M. Jones, Organometallics 1991, 10, 913-917.

[28] R. A. Periana, R. G. Bergman, J. Am. Chem. Soc. 1986, 108, 7346-7355.

[29] S. Tobisch, Chem. - Eur. J. 2005, 11, 3113-3126.

[30] J. D. Debad, P. Legzdins, R. J. Batchelor, F. W. B. Einstein, Organometallics 1993, 12, 2094-2102.

[31] N. H. Dryden, Peter. Legzdins, James. Trotter, V. C. Yee, Organometallics 1991, 10, 2857-2870.

[32] S. P. Semproni, W. S. McNeil, R. A. Baillie, B. O. Patrick, C. F. Campana, P. Legzdins, Organometallics 2010, 29, 867-875.

[33] M. Etienne, A. S. Weller, Chem. Soc. Rev. 2014, 43, 242-259.

[34] B. G. Harvey, R. D. Ernst, Eur. J. Inorg. Chem. 2017, 2017, 1205-1226.

[35] N. H. Dryden, Peter. Legzdins, R. J. Batchelor, F. W. B. Einstein, Organometallics 1991, 10, $2077-2081$.

[36] N. H. Dryden, P. Legzdins, S. J. Rettig, J. E. Veltheer, Organometallics 1992, 11, 2583-2590.

[37] C. Adamo, V. Barone, J. Chem. Phys. 1999, 110, 6158-6170.

[38] M. J. Frisch, et al, n.d.

[39] D. Andrae, U. Häußermann, M. Dolg, H. Stoll, H. Preuß, Theor. Chim. Acta 1990, 77, 123-141.

[40] A. W. Ehlers, M. Böhme, S. Dapprich, A. Gobbi, A. Höllwarth, V. Jonas, K. F. Köhler, R. Stegmann, A. Veldkamp, G. Frenking, Chem. Phys. Lett. 1993, 208, 111-114.

[41] K. Fukui, Acc. Chem. Res. 1981, 14, 363-368.

[42] H. P. Hratchian, H. B. Schlegel, in Theory Appl. Comput. Chem. First 40 Years, C. E. Dykstra, G. Frenking, K. S. Kim And G. Scuseria, Eds., Amsterdam, 2005, p. 195.

[43] A. V. Marenich, C. J. Cramer, D. G. Truhlar, J. Phys. Chem. B 2009, 113, 6378-6396.

[44] S. Grimme, S. Ehrlich, L. Goerigk, J. Comput. Chem. 2011, 32, 1456-1465.

[45] S. Grimme, J. Antony, S. Ehrlich, H. Krieg, J. Chem. Phys. 2010, 132, 154104.

[46] H.-J. Liu, J. Guihaumé, T. Davin, C. Raynaud, O. Eisenstein, T. D. Tilley, J. Am. Chem. Soc. 2014, 136, 1399113994.

[47] A. E. Reed, L. A. Curtiss, F. Weinhold, Chem. Rev. 1988, 88, 899-926.

[48] H. H. Storch, N. Golumbic, R. B. Anderson, In The Fischer-Tropsch and Related Syntheses, 1951.

[49] G. M. Sheldrick, Acta Crystallogr. Sect. A 2008, 64, 112-122.

[50] L. J. Farrugia, J. Appl. Crystallogr. 1999, 32, 837-838. 
[51] L. Farrugia, J. Appl. Crystallogr. 1997, 30, 565. 